\title{
Infectious Diseases: Annual review of significant publications
}

\author{
Hobart A. REIMANN \\ M.D.
}

The Hahnemann Medical College and Hospital of Philadelphia, U.S.A. 19102

\section{Introduction}

Yearly reviews since 1935 recorded significant contributions to knowledge about infectious diseases. On the occasion of this, my thirty-fifth consecutive annual review, it is of interest to pause and recall some of the advances made during that time.

Momentous events included the introduction of practical antimicrobic drugs by Domagk, by Fleming and by Waksman; Avery's discovery of DNA and RNA pertinent to microbic genetics; recognition of autoimmunity and of various globulin and complement components as related to infection; the development of electron microscopy; and several wars that emphasized exotic diseases. Regarding antimicrobics, proper therapy reduced the deathrate of bacterial pneumonias, coccal sepsis, endocarditis, tuberculosis, syphilis, rickettsioses, typhoid and plague. The incidence of rheumatic fever and mastoiditis lessened. Available antimicrobic drugs reached the limit of effectiveness. Staphylococci, Gram-negative bacilli and fungi assumed importance as drug-resistant pathogens. Therapeutic use and misuse of antimicrobics, immunosuppressive drugs and corticosteroids brought about diseases caused by these agents and by resulting opportunistic invaders.

Influenza virus was the first of many respiroviruses subsequently discovered. Viral pneumonias were distinguished from those of bacterial origin. Viruses also proved to be causes of mild dysentery. The advent of Ender's cultural technique aided virology. Vaccines against poliomyelitis, yellow fever, measles, mumps, rubella and influenza became available. Pneumotropic, enterotropic, neurotropic, and polytropic viruses were discovered. Cytomegalovirosis, herpes simplex, rubella, and toxoplasmosis as well, proved to be congenital infections. The relation of viruses to cancer and the significance of virus-like particles in tissues during neoplastic and systemic diseases entailed much research without conclusive results. Attempts began to find antiviral drugs and to determine the role of interferon in infections.

Insecticides controlled vector-borne malaria, typhus, leishmaniasis, sandfly fever and several neural viroses. Prompt rehydration made cholera a benign

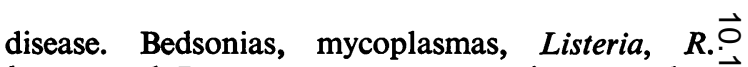
burneti and $P n$. carinii came to attention as patho- $\vec{\omega}$ gens. Inapparent and previously ignored mild attacks of disease when included in spectrums of severity 80 raised the previously reported statistical incidence 3 and lowered the recorded death-rates of polio- $t$ myelitis, typhoid, shigellosis, yellow fever, melioi-ir dosis, cholera and plague. Histoplasmosis and cocci- $-\infty$ dioidomycosis, once regarded as fatal, emerged as widespread, usually mild diseases. Epidemiologic $N$ measures, vaccines and antimicrobic drugs when 을 applied alone or in combination, held promise to eradicate some infections, but not in the foreseeable future.

During the past year, antimicrobic therapy, $\vec{\omega}$ opportunistic, nosocomial and iatrogenic infections received continued attention. The importance of animals and birds as reservoirs of microbes was affirmed. Vaccines for measles, rubella, influenza, adenoviral and other infections were further tested with variable results. Cholera reappeared in epi- $\frac{0}{\varnothing}$ demics. A causal relation of herpes-like virus to 2 infectious mononucleosis and lymphomas was $\overrightarrow{\overrightarrow{0}}$ proposed. Much interest and many publications concerned the Australia antigen and hepatitis. Despite the importance of infectious diseases, those of other origin dominated interest. Among eighty-O six papers on the 1970 programme of the Association of American Physicians, four dealt primarily with infections.

\section{Antimicrobic therapy}

Penicillin or ampicillin and streptomycin cured $\stackrel{ }{2}$ thirty of thirty-six patients with enterococcal endo- $\frac{7}{0}$ carditis. Adverse reactions affected fifteen, one with fatal enteritis. ${ }^{1}$ Vancomycin and streptomycin were $N$ recommended for treating enterococcal endocarditis $N$ in patients intolerant to penicillin. ${ }^{2}$ Cloxacillin $N$ therapy failed to influence the course of septic ${ }_{\sigma}^{\omega}$ lesions. ${ }^{3}$ Staphylococci increasingly resisted methicillin. ${ }^{4}$ Among twenty-one tested agents, ampicillin, $\frac{O}{\circ}$ penicillin and vancomycin in that order were most $\stackrel{\oplus}{\rightarrow}$ active against Group D Streptococci. ${ }^{5}$ Gentamicin successfully controlled serious infections caused by E. coli and Enterobacter. Those caused by Proteus $\mathbb{\nabla}$

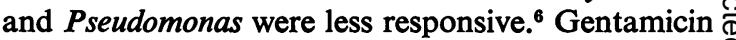


was 100 times more active in vitro at $\mathrm{pH} 8.5$ than at pH 5 against most strains of Gram-negative bacilli. Concurrent administration of an alkalizing agent allowed smaller effective amounts of gentamicin and erythromycin.?

The value of cephalothin, cephaloridine, cephaloglycin and cephalexin was assessed. ${ }^{8}$ Forty-two papers about cephalosporins appeared in a supplement (Oct. 1970) of the Postgraduate Medical Journal. Cephalexin controlled staphylococcal infections of soft tissues. ${ }^{9}$ It was useful for treating urinary tract infections in moderately uremic patients. ${ }^{10}$

Carbenicillin, $18 \mathrm{~g}$ daily, controlled pseudomonal bronchial infections. ${ }^{11}$ The drug caused improvement in seven of ten children, but four died. Bacilli persisted in sputum. ${ }^{12}$ It was active in vitro against many Gram-negative bacilli ${ }^{13}$ and was useful for urinary tract infections with Pseudomonas and Proteus. Bacillary resistance developed rapidly. ${ }^{14}$ According to two reports, carbenicillin has not fulfilled its promise. Of fifty-five pseudomonal infections only sixteen were cured. Superinfections often ensued. ${ }^{15,16}$ All of thirty-eight strains of Bacteroides were sensitive to chloramphenicol representing one of the few indications for its use. ${ }^{17}$

In a 10-year period no evidence of increasing antimicrobic-resistance appeared among isolates of $E$. coli or Klebsiella. Resistance actually declined..$^{18}$ The report is at variance with others wherein resistance of the bacilli in question was far greater.

During therapy of mycoplasmal pneumonia, microbic resistance increased greatly to erythromycin and to five other antimicrobic drugs as well. ${ }^{19}$ Erythromycins are the first choice only for mycoplasmal infections. ${ }^{20}$

The value of rifampicin for treating tuberculosis was established. It may exceed isoniazid and streptomycin in efficacy because of its rapid action, low toxicity and oral administration. ${ }^{21}$ Rifampicin was of especial value when the bacilli resisted other drugs. ${ }^{22}$ The drug may be of value for leprosy. ${ }^{23}$ It also has antiviral action. ${ }^{24}$ It reduced the percentage of meningococcal carriers by $80 \%$ when given orally. ${ }^{25}$ Lincomycin controlled actinomycoses in four patients allergic to penicillin. ${ }^{26}$ Clindamycin, a drug of second choice for coccal infections may replace lincomycin as an oral agent. ${ }^{27}$ Herrell reviewed the historical development of antimicrobics after the first one, pyocyanase, was isolated in 1899. ${ }^{28}$

Ramycin restricted growth of Gram-positive bacteria. ${ }^{29} \mathrm{New}$ antifungal agents are denofungin, scopafungin, ticlatone, zorbamycin, cephapirin, nifungin and clotrimazole.

\section{Misuse}

A neutropenic child had previously received penicillin and a sulfonamide for a cold and again for gingivitis; erythromycin for small furuncles; tetracycline for infectious mononucleosis, and penicillin for nonstreptococcal sore throat. None of this therapy was indicated. ${ }^{30}$ There is no justification for the use of tetracycline or any other antimicrobic in the prevention or treatment of minor viral respiratory tract disease. ${ }^{31}$

In seven hospitals, $30.6 \%$ (range $24-75 \%$ ) of patients received antimicrobic therapy, oftenest on the pediatric and surgical services. Probably $62 \%$ of these were treated prophylactically. Only $38 \%$ of treated patients had recorded evidence of infection. ${ }^{32}$ Evidently the wastage of antimicrobic drugs continues unabated. In my own 450-bed hospital the cost of antimicrobics to patients in the past year was $\$ 290,000$, most of it unnecessary. Physicians, patients and third-party payers evidently make little or no effort to reduce the misuse.

\section{Unwanted effects}

The number of bacteremic patients in Finland's hospital doubled between 1935 and 1953, and almost doubled again by 1965 . Gram-negative bacillary sepsis increased threefold. That from Pseudomonas appeared after 1943 and from Klebsiella-enterobacter after 1957, dependent upon the increased use and ensuing resistance to antimicrobic drugs. Mima, Herellea and Serratia appeared as pathogens. Deaths from sepsis increased each year: in 1965 twice as many as in 1953. The mortality rate in 1965 equalled that of 1941 before antimicrobics were available. To reverse the trend, unnecessary and improper use of antimicrobial agents, particularly for prophylaxis will have to be modified or stopped. ${ }^{33}$ In a surgical ward, cessation of all antimicrobic therapy reduced the incidence of Klebsiella infections. ${ }^{34}$

Antimicrobic therapy in early childhood may interfere with the development of immunity against $H$. influenzae and account for the increasing frequency of Type $B$ infections in adults. ${ }^{35}$ Renal failure, deafness and paralysis accompanied irrigation of body cavities with antimicrobic drugs for prophylaxis or therapy. ${ }^{36}$ Therapy is hazardous in patients with myasthenia gravis. ${ }^{37}$

Penicillin given intravenously caused convulsions. $^{38}$ Anaphylactoid reactions followed orally given ampicillin. ${ }^{39}$ Exanthems occurred during infectious mononucleosis. ${ }^{40}$ Ampicillin and carbenicillin caused local injury after intramuscular injection. ${ }^{41}$ Carbenicillin, like penicillin, in large dosage during renal failure is neurotoxic. ${ }^{42}$ Encephalopathy appeared from chloramphenicol. ${ }^{43}$ Sodium colistimethate caused adverse renal reactions in $20 \%$ of 288 patients, neurotoxicity in $7 \%$ and respiratory difficulty in $2 \%$. Harmful effects contributed to the death of $4 \%$ of patients. ${ }^{44}$ Oral administration of 
neomycin resulted in six instances of ototoxicity during hepatic encephalopathy. Paromomycin may be similarly dangerous. ${ }^{45}$ Ototoxicity affected five patients receiving gentamicin during renal failure. ${ }^{46}$ Kanamycin-resistant Klebsiella caused bacteremia in six infants and spread to others in a nursery. ${ }^{47} \mathrm{Six}$ of seventy-five patients treated with cephaloridine developed a direct reaction to the Coomb's test but without haemolysis. ${ }^{48}$ Cephaloridine in large dosage is nephrotoxic, especially for previously injured kidneys. ${ }^{49}$ Rifampin caused jaundice in four of fifty tuberculous patients ${ }^{50}$ and thrombocytopenia in another patient. ${ }^{51}$ Hepatitis was a rare occurrence during isoniazid therapy. ${ }^{52}$

Methicillin-resistant staphylococci infected six patients in a hospital. Two died. Transmission apparently was hand-borne. ${ }^{53}$ Elimination of antimicrobic-sensitive faecal flora by antimicrobic drugs induced urinary tract infections with resistant bacteria in infants. ${ }^{54}$

When all precautions have been observed before therapy, physicians are not held negligent should adverse reactions ensue. ${ }^{55}$

\section{Viral respiratory tract infections Influenza}

Polyvalent influenza $A_{2}$ vaccine gave a high degree of protection against infection in 1968-69. The antibody response equalled that after natural infection. ${ }^{56}$ According to other experience, adjuvant influenza vaccine afforded moderate protection during outbreaks, but not among preschool age children, to outbreaks of either A or B infection. ${ }^{57}$ Recent vaccination or multiple prior vaccinations of military personnel failed to prevent $\mathbf{A}_{2}$ influenza. Twelve per cent or more of men were infected. ${ }^{58}$ The incidence of influenza B during an epidemic was the same in vaccinated and unvaccinated victims. ${ }^{59}$ Pandemic influenza, so far, has resisted control. ${ }^{60}$ Aerosol vaccine increased antibody in pharyngeal secretions of volunteers six-fold and persisted a year. ${ }^{61}$ Meningoencephalitis of unknown cause followed 2 weeks after vaccinating an adult. ${ }^{62}$

In a controlled study, 200-300 mg of amantadine given for 10 days prevented influenza $A_{2}$ in eighteen inoculated subjects. Four of eighteen control persons were infected but had a greater antibody response. ${ }^{63}$ Russian physicians found amantadine to be about $80 \%$ effective in preventing severe $\mathrm{A}_{2}$ influenza when given before symptoms appear. Influenza $B$ was not influenced. ${ }^{64}$ Therapeutically, the drug was said to cause more rapid improvement of influenza $\mathbf{A}_{2}$ patients than of control subjects without affecting virus shedding or increase of antibody titre. ${ }^{65}$

Severe myositis of the legs affected twenty-six children during influenza. ${ }^{68}$ Acute myoglobinuria accompanied Type $\mathbf{A}$ influenza in a patient. Other respiroviruses rarely cause similar troubles. ${ }^{67}$ During an epidemic of A Hong Kong virus infection, among 127 patients, ten had mild pneumonia and two died. Ten had diffuse pneumonia caused by the virus itself, of whom six died. Cough, sore throat and fever $\stackrel{\vec{\rho}}{\rightarrow}$ were commoner than myalgia, headache and 0 malaise. ${ }^{68}$

Among 399 patients, chiefly children during a 4- $\frac{\bar{m}}{\partial}$ year period from whom parainfluenza viruses were $\stackrel{\Phi}{\complement}$ isolated, pharyngitis and colds predominated. The rest had croup, bronchitis, and pneumonia. Laboratory diagnoses were ready within 5 or 10 days. ${ }^{69} \stackrel{\circ}{\circ}$ Parainfluenza 3 virus caused mumps-like parotitis in $\vec{\omega}$ two children. ${ }^{70}$ Parainfluenza 2 vaccine administered $\stackrel{\circ}{\circ}$ as an aerosol gave a better neutralizing antibody response than after subcutaneous injection. ${ }^{71}$

\section{Adenoviruses}

Adenoviruses Types 1-7 isolated from infants and $\stackrel{\oplus}{\infty}$ children with respiratory tract infections also were $\omega_{\omega}^{\omega}$ present in two thirds of healthy children, many of $N$ whom probably were inapparently infected..$^{72}$ New 은 Types 32 and 33 were isolated from infants. ${ }^{73}$ Live and inactivated adenovirus 4 vaccine given orally reduced respiratory tract infections among recruits $\vec{D}$ by $50 \% \cdot{ }^{74}$ Vaccination protected about $75 \%$ of other $\overrightarrow{6}$ army recruits. ${ }^{75}$ In another study, adenoviral $y \geq$ vaccine eliminated homologous infections, but these were replaced by infections with Types 7 and 29 . Polyvalent vaccine is necessary. ${ }^{76}$ Faulty care caused a hospital epidemic of forty-four cases of adenoviral keratoconjunctivitis. ${ }^{77}$ Surprisingly, typical pertussis $\frac{\circ}{D}$ may be caused by adenoviruses, not always by Bordetella. Types 1, 2, 3, or 5 were present in eleven of thirteen infants with whooping cough. The circumstance may explain the occasional failure of pertussis vaccine. ${ }^{78}$ Rich and McCordock in 1932 had noted inclusion bodies in the lungs. It may be recalled that a parainfluenza virus once was regarded as "croup associated'.

\section{Other viruses}

Antigenic variants of several rhinoviruses were isolated. The prototype of immune serum neutralized them weakly or not at all. ${ }^{79}$ The circumstance re- $\frac{D}{0}$ sembles the variability of influenza viruses and will have a bearing on the ultimate value of vaccine. N Eighty-nine serotypes are known. ${ }^{80}$ Rhinoviremia $N$ occurred in two infants who died suddenly. ${ }^{81}$ In- N jected poly I : C complex has promise for the preven- $C$ tion of some viral infections especially with the rhinoviruses. $^{82}$

Tyrrel described the technique which discovered $\stackrel{\mathbb{D}}{\mathbb{S}}$ the coronaviruses. Viral particles resemble the solar corona, hence the name. In inoculated volunteers, they caused colds differing from rhinovirus infection $\mathbb{D}$ by a longer incubation period, shorter duration, $\frac{?}{\mathbb{D}}$ 
more catarrh, less sore throat and cough. ${ }^{83}$ According to antibody responses, epidemics of coronavirus infection affected adults oftener than children. ${ }^{84}$ In an outbreak in 1967 , about $34 \%$ of a population were affected. The neutralization test detects both recent and past infections. Complement-fixing bodies were evanescent. ${ }^{85}$

Respiratory syncytial virus may cause death from mucosal necrosis and pulmonic damage or by allergic effect after reexposure to the virus. ${ }^{86}$ Infection in the newborn was mild. Severe infection in later life may be ascribed to specific sensitization. Fluorescent antibody technique enabled early diagnosis. ${ }^{87}$

Coxsackie B virus caused upper respiratory tract disease in 227 of 311 patients chiefly children from whom the virus was isolated. The rest had fever and headache only, or pleurodynia, meningoencephalitis, abdominalgia or pericarditis. ${ }^{88}$ Aerosolized coxsackie virus $A_{21}$ infected each of twenty-one volunteers as shown by virus isolation and antibody response. Respiratory tract disease occurred in most and involved the lower portion in four. ${ }^{89}$

An extensive review covered progress in the control of viral and mycoplasmal respiratory tract infections. Much has been learned, but these infections persist. Differences in pathogenicity and of local or systemic immunity impedes progress in developing vaccines. ${ }^{90}$

\section{Viral hepatitis}

Several articles summarize knowledge about the relationship of the Australia (AU) antigen and antibody to hepatitis. ${ }^{91,92,93}$ Imperfect differentiation of infectious (IH, type A, MS-1, short incubation) hepatitis from serum (type $\mathrm{B}, \mathrm{SH}, \mathrm{MS}-2$ ) hepatitis at first confused the issue. Furthermore, AU antigen present during leukaemia, Hodgkin's disease, mongolism, polyvasculitis, leprosy and in healthy persons raised doubt as to its causal relation. Hepatitis probably was, or had been, present to account for the antigen, or the supposed virus caused different diseases. Four of eleven patients with polyarteritis and hepatic involvement had AU antigenemia probably as an immune reaction. ${ }^{94}$ Some uncertainty resolved when the antigen and virus-like particles were demonstrated only in cases of $\mathrm{SH},{ }^{95}, 96,96 \mathrm{a}$ not during epidemics of $\mathrm{IH} .{ }^{97}$ The particles also were present in patients with biliary cirrhosis. ${ }^{98}$ Antiserum clumped the $42 \mu \mathrm{m}$ sized particles $^{99}$ which may be the causal agent. ${ }^{100}$ Serum hepatitis induced by injecting plasma containing the particles and SH antigen supported their etiologic relationship. ${ }^{101,} 102$

Plasma from hepatitis victims caused cytopathic effects in tissue culture cells. Plasma from the same person prior to illness did not. Marmosets injected with IH serum developed serologic evidence of infection and cytopathic changes in the liver. ${ }^{103}$ The results tend to support the work of McLean, Rightsel and others who incriminated a viral agent in $1956 .{ }^{104}$

$\mathrm{AU}$ and $\mathrm{SH}$ antigen are the same. The significance of 'smooth muscle' antibody during chronic hepatitis ${ }^{105,106}$ and of a 'new' antigen present during three epidemics of $\mathrm{IH}^{107}$ is undetermined. The far greater prevalence of $\mathrm{SH}$ antigen in residents of the tropics than among blood-donors in New York City, suggested an arthropod transmission of the infection. ${ }^{108}$ In a Danish hospital among 10,000 patients, thirty-five had the SH antigen, of these six had acute hepatitis, seven had chronic hepatitis or cirrhosis and twenty-two had no demonstrable hepatic disease. ${ }^{109}$

Blood transfusion annually accounts for about 30,000 cases of SH and more than 1500 deaths in the U.S.A. No doubt, many inapparent or undiagnosed mild attacks occur. According to Medical News in the Journal of the American Medical Association of 23 November, cessation of one and two unit transfusions would prevent $65 \%$ of $\mathrm{SH}$.

The absence of demonstrable AU antigen in donors' blood does not guarantee freedom from the virus. ${ }^{110}$ Hepatitis developed in recipients of antigennegative blood. ${ }^{102}$ Other means are needed to identify hazardous blood-donors. A precipitin test detected AU antigen in $0.1-0.5 \%$ of normal persons. ${ }^{111}$ Donor erythrocytes washed with a special technique reduced the incidence of hepatitis. ${ }^{112}$ Rapid screening tests are available. ${ }^{113,114}$

Re-examination of soldiers who had had hepatitis 20 years before gave no evidence of risk of developing hepatic cirrhosis. ${ }^{115}$

\section{Rubella}

During the 1966 epidemic, 20,000 defective children were born eventually entailing a cost of $\$ 2$ billions for care. The only significant undesired effect during the first year after vaccination among 13 million persons was transient arthralgia. ${ }^{116}$ Of three vaccines tested, two caused neither rubella nor arthralgia but the third caused both. ${ }^{117}$ Therapeutic abortion was performed 8 weeks after rubella vaccination during the third week of unsuspected pregnancy caused an intrauterine infection. ${ }^{118}$ The incidence of rubella was reduced among Japanese schoolboys vaccinated subcutaneously during an epidemic as compared with control subjects. Intranasal vaccination seemed to be effective. ${ }^{119}$

Vaccination occasionally fails. Inapparent rubella affected $50 \%$ of children 5 months after vaccination. ${ }^{120}$ Eighty per cent of vaccinated men and $3.4 \%$ of naturally immune men were reinfected during an epidemic as shown by serologic tests. Each of twentysix susceptible men was infected. ${ }^{121}$ The degree of immunity conferred is uncertain and vaccination may confuse the issue. ${ }^{122}$ It is doubtful if rubella can 
be eradicated by vaccination. Immune globulin failed as a preventive measure. ${ }^{123}$

As in the case of polio vaccine, vaccine-strain rubella from vaccines may infect others. ${ }^{124}$ In another study, however, transmission did not occur. Antibody level in vaccinees was lower than that after natural infection. The duration of induced immunity is unknown. ${ }^{125}$ Failure of vaccination at times may be due to deteriorated vaccine. Official recommendations for vaccination were outlined. ${ }^{126}$ The advantages, disadvantages and unknown factors regarding rubella vaccines were presented in three papers in the September issue of the American Journal of Epidemio$\log y$.

\section{Smallpox}

In a 9-year period, sixty-eight deaths from vaccinia necrosum, encephalitis, eczema vaccinatum and mucocutaneous fever were attributed to smallpox vaccination in the U.S.A. Twenty-four were infants. Some persons acquired vaccinia from vaccinees. ${ }^{127}$ Direct inquiry of physicians disclosed complications to be ten to seventy times greater than the rate computed by national surveillance. Eightyfour per cent occurred after primary vaccination. The rates of potentially fatal encephalitis and vaccinia necrosum were 12 and $1.5 /$ million respectively. ${ }^{128}$ In 326 persons without serious sequels, ocular vaccinia followed vaccination in $70 \%$, and by contact with vaccinees $19 \% \cdot{ }^{130}$ Nine instances with five deaths from vaccinia necrosum followed vaccination for the futile treatment of chronic herpes hominis viral infection. ${ }^{130}$ When only $50 \%$ of a population had been vaccinated, an outbreak of smallpox affected $2 \cdot 6 \% .{ }^{131}$ Smallpox may be airborne. ${ }^{132}$ Serologic evidence suggested the natural transmission of smallpox from man to monkeys. These may be a reservoir of infection. ${ }^{133}$

Varicella in a child was accompanied by genual arthritis. ${ }^{134}$ Meningoencephalitis occurred in eight patients with herpes zoster. Most patients recovered. Corticosteroid therapy was not helpful. ${ }^{135}$ Chickenpox and zoster were interchanged among patients and personnel in a hospital. Zoster occasionally is exogenous in origin especially when host-resistance is impaired. ${ }^{136}$ Other evidence suggests that previous exposure, latency and reactivation rather than exogenous reinfection from patients accounts for zoster. ${ }^{137}$

Antimeasles vaccination failed to affect the course of an epidemic among Chicago school children. ${ }^{138}$ Koplik spots share giant cells and virus particles with dermal lesions. ${ }^{139}$ During a mumps epidemic, 126 victims were observed. Twenty-five per cent of family contacts were inapparently infected. Secondary household infections ranged from $14 \%$ to $46 \% \cdot{ }^{140}$ Hand, foot, and mouth disease (stomatitis, pedal and manual exanthems) caused by coxsackievirus $\mathrm{A} 16$ affected children in Baltimore. ${ }^{141}$

The demonstration of specific antibody in patients $\stackrel{\varrho}{c}$ with trachoma may lead to the development of $a \stackrel{.}{\Rightarrow}$ vaccine. ${ }^{142}$ It is doubtful, as suggested, that vaccine $\stackrel{\text { ? }}{?}$ applied locally will be effective. Infection is in the? tissue not in the exudate.

\section{Encephalitis}

Oral application of rabies virus killed mice. Gastric secretion failed to inactivate the virus. ${ }^{143}$ Evidently rabies virus can penetrate the enteric and $\stackrel{\circ}{-}$ the pulmonary mucosa. This accounts for rabies $\vec{\omega}$ previously reported in spelunkers. A newspaper re- $\rho$ corded the probable first known recovery fromo rabies: A boy bitten by a rabid bat was promptly

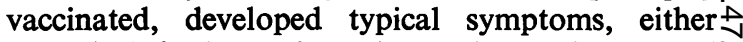
from the infection or from the vaccine, and recoveredir after three weeks. By electron microscopy the Negripo bodies of rabies were composed of viral particles as ${ }_{\omega}^{\omega}$ intracytoplasmic bodies. ${ }^{144}$ Methods for the control ${ }_{\circ}^{N}$ of rabies were outlined. ${ }^{145}$

Brain tissue from subacute sclerosing panencepha- $\vec{c}$ litis yielded measles viruses. They were the same antigenically as 'wild' viruses, but differed in abilityळ to neutralize antibody to wild viruses and in their $\overrightarrow{0}$ growth. ${ }^{146}$ Perhaps long residence in the brain $=$ changed the nature of the pathogen. Besides measles: like virus, an unclassified virus was in brain tissue offo two patients. ${ }^{147}$ Encephalitis produced in hamsters by inoculating material from brains of patients witho subacute sclerosing panencephalitis provides a con- $-\frac{\mathrm{D}}{\mathrm{D}}$ venient method for study. ${ }^{148}$ Patients with multiple sclerosis have slightly higher titres of measles anti-윽 body than normal persons. ${ }^{149}$

A series of articles about kuru, regarded as viral encephalopathy, appeared in the January, 1970, issue of the American Journal of Tropical Medicine 3 and Hygiene. The first indigenous case of Venezuelanencephalitis was observed in Florida. Specific antibody was demonstrated in five of 353 residents in the vicinity. ${ }^{150}$ The infection probably is endemic.

Migratory birds appeared to transport arboviruseso southward. ${ }^{151}$ One wonders whether the reverse? occurs when they return? Birds probably haveo carried microbes to and fro for ages, but population growth has increased human sources and recipientser of viruses. How did Venezuelan encephalitis virusN get to Florida, and California virus to Minnesota? Similar questions once pertained to the spread of plague eastward in the U.S.A. Research and discovery spread eastward to the residence limit of rodent hosts.

That arboviruses may remain latent in the human brain for years was indicated by the recovery ofo Langat virus from brains of mice for 261 days after intraperitoneal inoculation. ${ }^{152}$ The transmission of 
mink encephalopathy to monkeys further supports a view that viral encephalopathies may be common to man and animals. ${ }^{153}$

Virus-like particles were in cerebral tissue of two patients with Creutzfeld-Jakob disease. ${ }^{154}$ Since 'slow' viral infections have been associated with chronic encephalitis, other diseases may have similar origin. Antibody to measles and parainfluenza 1 viruses appeared during systemic lupus erythematosus and Reiter's disease. ${ }^{155}$ Their significance is undetermined.

During an outbreak in Seattle of Echovirus 30 disease, sixty-four persons were infected. Their families contained 291 members among whom the serologic infection rate was $80 \%$. It was $24 \%$ in the total population. Apparently, thousands of cases occurred of which more than half were asymptomatic. Few were diagnosed as meningoencephalitis. ${ }^{156}$

Investigations by electron microscopy demonstrated endothelial inclusions resembling myxovirus in patients with systemic lupus erythematosus and rheumatoid arthritis. Whether they are causal or evidence of injured tissue is unknown. ${ }^{157}$

\section{Viral meningoencephalitis}

During an epidemic of meningitis in Florida, one of fifteen known victims died. Echo 9 virus caused eight infections, meningococci five and in several both microbes were pathogenic. ${ }^{158}$ As in pneumonia, viral infections probably predisposed patients to coccal invasion. In an outbreak of Echovirus 6 infection, eleven children had meningoencephalitis, seven had pharyngitis and five had myalgia. As unusual features, one had pericarditis and one had nephritis. ${ }^{159}$ Echovirus 30, detected in the spinal fluid by culture in human diploid cells, induced minimal or no pleocytosis. ${ }^{160}$ Gsell presented current clinical and therapeutic problems about meningitis and encephalitis. ${ }^{161}$

\section{Other viroses}

\section{Herpes hominis}

Disseminated herpes affected five infants, one fatally. ${ }^{162}$ Bleeding and intravascular clotting were fatal in another instance. ${ }^{163} \mathrm{~A}$ newborn infant contracted infection from the mother who had been infected by the husband's penile herpes. ${ }^{164}$ Genital herpes antibody often was present in cervical squamous neoplasia as if it might have been the cause. ${ }^{165}$ Herpetic paronychia affected medical personnel exposed to patients' oral lesions. ${ }^{166}$ The virus may have caused hepatitis in one patient ${ }^{167}$ and acute prostatitis in another. ${ }^{168}$ It occasionally becomes pathogenic in burned patients. ${ }^{169}$ Among six patients with encephalitis treated with intravenous idoxuridine, two died. The others recovered but had either stomatitis, bacterial infection, marrow depression or alopecia. ${ }^{170}$

\section{Herpes-like $(E B)$ virus and cytomegalovirus}

Isolation of these viruses or the presence of antibodies during lymphomas, nasopharyngeal carcinoma, infectious mononucleosis and sarcoidosis ${ }^{171}$ is of unknown significance. Increased titre to EB virus appeared in $25 \%$ of patients with Hodgkin's disease, which is less than during Burkitt's lymphoma. ${ }^{172}$ The etiologic relation of the viruses to the diseases is in question. ${ }^{173}$ In one instance, infectious mononucleosis developed during acute leukaemia. ${ }^{174}$ Both viruses often are commensal. The matter was summarized elsewhere. ${ }^{\mathbf{1 7 5}}$

Thirty-seven of forty German patients with Burkitt's lymphoma carried EB virus, ${ }^{176}$ but four American patients did not. ${ }^{177}$ Malaria was said to be the only single identifiable factor common to, or more or less limited to, regions where Burkitt's lymphoma is prevalent. ${ }^{178}$ Yet this lymphoma occurs in malaria-free Germany and elsewhere. Is EB virus causal or an opportunistic invader? The problem was discussed editorially. ${ }^{179}$ In an American, Burkitt's tumor appeared 16 months after an attack of mononucleosis. ${ }^{180}$

EB or cytomegalovirus seemed to cause fifty-four cases of infectious mononucleosis-like disease minus the heterophile agglutinin. ${ }^{181}$ Cultivated marrow cells from patients induced malignant tumours when injected into hamsters. ${ }^{182}$ Neither virus was associated with infectious lymphocytosis. ${ }^{183} \mathrm{~EB}$ viral antibody was present in $83 \%$ of control subjects. ${ }^{184}$ Antibody increased in college students and persisted for years. Twenty-eight of ninety-seven had had mononucleosis and fifteen others either had been inapparently infected ${ }^{185}$ or had had other disease. ${ }^{186}$ In a family of twenty-one, seven index patients had increased titres. Seven others acquired antibody of whom five had atypical lymphocytes and a positive heterophile reaction. ${ }^{187}$ About $87 \%$ of recruits of low economic status had antibody for EB virus. The incidence of infectious mononucleosis among them was $18 / 1000$ and for Vietnam veterans $24 / 1000$. Seroconversion exceeded hospitalization ten-fold.

EB viral infections in childhood may be dormant for years, manifested by persistent antibody and occasional mild nasopharyngeal discomfort. None of the tested children had mononucleosis. ${ }^{189}$ All Aleutian children more than 2 years old had EBV antibody. ${ }^{177}$ Antibody for EB virus appeared after cardiac surgery and transfusion of blood in eighteen of 229 patients. Antibody against cytomegalovirus developed in eighty. ${ }^{190}$

The Henles reviewed the sequential development of knowledge and the primary contributions they made to the subject. Accordingly, EBV most likely 
causes the major form of infectious mononucleosis. Its relationship to lymphoma is less firmly established, but has become more probable. ${ }^{191}$

Cytomegalovirus. Congenital infection of twentysix infants with cytomegalovirus was overt in only one. Neurologic difficulties appeared in three within 8 months. ${ }^{192}$ In another study the virus was absent in healthy neonates. It was present in $60 \%$ of those between 5 and 9 months old but excretion ceased within a year. Virus also was found in $10 \%$ of women during pregnancy and in $28 \%$ at term. ${ }^{193}$

\section{Viral dysentery}

'Winter vomiting disease' affected 300 college students and people in the community. As usual, 'food poisoning' was suspected but disproved. No virus was isolated. ${ }^{194}$ Seventeen monkeys inoculated with reovirus developed leucopenia and slight fever. Thirteen had diarrhoea lasting 6-15 days. ${ }^{195}$ Ileocolitis during measles in a child apparently was viral in origin. ${ }^{196}$ The use of human foetal intestinal cell cultures may facilitate the recovery of viruses from that tract. ${ }^{197}$

\section{Exotic viroses}

Five papers about Lassa fever, a 'new' disease in Nigeria, appeared in the July 1970 issue of the American Journal of Tropical Medicine and Hygiene. Person-to-person transfer occurs. Prominent features are viremia, pharyngitis, myositis, myocarditis, leucopenia and thrombocytopenia. Mild and inapparent infections occur. Virus persists in the throat and urine for weeks. The mode of transmission is unknown. The virus particles resemble those of lymphocytic chloriomeningitis, Machupo and Tacaribe viruses. The Yale Journal of Biology and Medicine of April 1970, contained five articles about dengue haemorrhagic fever. Asian viral haemorrhagic fevers were the subject of a review in the November 1970 Journal of Infectious Diseases. They are related to infections in Africa and South America.

\section{Virus and cancer}

Antibody to genital herpes virus appeared in $95 \%$ of patients with cervical carcinoma and in $55 \%$ of control subjects. Virus may initiate the cancer but a causal association is uncertain. In normal women, antibody increases with advancing age and poor economic status. ${ }^{198}$ Similar results but with percentages of $83 \%$ and $35 \%$ respectively were reported by others. ${ }^{199}$ Some members of the herpes and cytomegalo groups of viruses are oncogenic. ${ }^{200}$ In other studies, antibody to herpesvirus type 2 was present in $83 \%$ of women with cervical cancer, in $30 \%$ with carcinoma in situ, but only in $9 \%$ to $22 \%$ of control subjects. Acquisition of antibody seemed to precede neoplasia. ${ }^{201}$ Is the virus causal or merely able to grow in injured tissue? The subject was discussed by Stoker. ${ }^{202}$

A sarcoma-specific antigen appeared in cultivated $\stackrel{C}{\hookrightarrow}$ sarcoma cells of patients and occasionally of normal genetic relatives. C-type particles like those of animal $\overrightarrow{0}$ sarcomas were present in human sarcoma cells. ${ }^{203}$ 음

Dermal deposits of malignant melanoma dis- $\frac{\bar{\omega}}{\bar{T}}$ appeared in six of ten patients after local smallpox $\mathbb{\Phi}$ vaccination. ${ }^{204} \mathrm{~A}$ virus from a monkey's mammary cancer grew in cell-culture. Animals inoculated with ${ }^{\text {s }}$ the cells will be observed for a year. Similar viral $\vec{\circ}$ particles were found in human cancers where they $\overrightarrow{\vec{\omega}}$ may have localized. ${ }^{205}$ Human embryogenic cells $\stackrel{\omega}{\omega}$ were susceptible to infection with feline leukaemia 8 and sarcoma viruses. The latter transformed the cells 3 to malignant ones. ${ }^{206}$ The development of an anticancer vaccine is an unlikely prospect. The C-type or particle of virus suspected as a cause of cancer is $\stackrel{\infty}{\infty}$ present in normal tissue. ${ }^{207}$

\section{Miscellaneous viral studies}

Electron microscopy disclosed virus-like intra- cellular particles in the kidneys of twenty-nine of thirty-nine patients with systemic lupus erythema- $\bar{D}$ tosus. Similar particles were in the glomerular endo- $\overrightarrow{0}$ thelium in patients with discoid lupus. Particles we absent in two patients receiving hydralazine. Tissue from patients with regional enteritis inoctif lated into mice seemed to contain a transmissible agent. Granulomas developed after 6-8 months. ${ }^{209}$

Interferon. A tilorone compound, probably an $\stackrel{\circ}{\circ}$ interferon, given orally to mice prevented infection against nine viruses. ${ }^{210}$ Inadequate production of $\overline{\bar{O}}$ interferon may favour dissemination of herpes zoster. Because patients with underlying neoplastic disease formed little or no interferon in chickenpox vesicles, zoster ensued. ${ }^{211}$ Besides an 'interference' factor, the reason why a host infected with one microbe can resist infection with another is unknown. Mice infected with Listeria were protected against inoculated pneumococci. Enhanced macrophage action probably occurred. ${ }^{212}$ Endotoxins given to animals altered resistance to parasitic, mycotic, bacterial and viral infections. The effect is due to interference of $\frac{D}{O}$ granulocytic diapedesis and exudation, or of phagocytosis by the reticuloendothelial system. ${ }^{213}$ Stimula- N tion of interferon production by poly $1: \mathrm{C}$ may $N$ provide a means to prevent or treat viral diseases. The July 1970 Archives of Internal Medicine contained a symposium about interferon. The information was summarized in the November 1970 Southern Medical Journal, page 1199 and in Science of $4 \mathbb{\&}$ December, page 1068. Persistent salmonellosis, probably because of defective phagocytosis as a familial trait, occurred in a woman whose children died from granulomatous disease. ${ }^{214}$ 
Procedures were described for identifying many viruses by combinations of ten pools of ten antisera each. ${ }^{215}$ The fluorescent antibody technique for rapid diagnosis of viral and bacterial infections also was described. ${ }^{216}$

\section{Mycoplasmas}

T-strain mycoplasmas live in the diseased urogenital tract of most patients, especially women. ${ }^{217}$ The microbes also were present in the cervix and urine of $84 \%$ of pregnant women, ${ }^{218}$ and in $92 \%$ of those with venereal disease. They may be pathogenic during pregnancy, ${ }^{219}$ but have no relation to precancerous changes. ${ }^{220}$ They were associated with $60-90 \%$ of cases of nongonococcal urethritis, but present in $25 \%$ of normal persons. Tetracycline or erythromycin controlled infection. ${ }^{221}$

Mycoplasma fermentans of ten is present in joints afflicted by rheumatoid arthritis. The microbic membrane inhibited leucocytic migration in twenty-nine of forty-three patients, but not in osteoarthritis or in normal persons. The inflammatory process may be a hypersensitive response. ${ }^{222}$ Intensive antimicrobic attempts, no doubt, are in the offing. Question arises -are they causal or opportunistic invaders? Myco. hominis daused dermal abscesses in the newborn. ${ }^{223}$

\section{Bacillary infections \\ Shigellosis}

Twenty-five food-borne outbreaks of shigellosis occured in the U.S.A. in a 5-year period. Sonne and Flexner bacilli accounted for $50 \%$ of the outbreaks. ${ }^{224}$ Carriers were the sources. After decades of absence, epidemics of Shiga dysentery in 1969 affected more than 100,000 victims and caused 8000 deaths in Central America. More than $50 \%$ of cases were asymptomatic. Tourists carried infection elsewhere. Sulphonamide drugs, tetracycline and chloramphenicol had no therapeutic effect. Ampicillin may be the drug of choice. Reports of the outbreak appeared in the September 1970 issue of the Journal of Infectious Diseases. Among naval personnel in Vietnam, ampicillin shortened the course and the carrier state. Kanamycin was ineffective. ${ }^{225}$ According to other opinion, no benefit can be expected from the treatment of acute salmonellar or shigellar dysenteries with antimicrobics. Their use often prolonged the carrier state. ${ }^{226}$

Thirty-eight soldiers had diarrhoea within 14 days of arrival in Aden. Salmonellae were present in two stools and a new serotype of $E$. coli in fourteen. ${ }^{227}$ A causal relationship was not established. Acute diarrhoea was considered a 'toxin' disease ${ }^{228}$ which is especially pertinent to cholera.

\section{Typhoid}

In three reports in the British Medical Journal, 8
August 1970, trimethoprim-sulphamethoxazole was as effective as choramphenicol for treatment and for typhoid carriers. No serious side-effects occurred. In another study, chloramphenicol given orally appeared in the blood sooner than after intramuscular injection. ${ }^{229}$ Typhoid was induced in volunteers according to reports in the 24 September and 1 October issues of the New England Journal of Medicine. Titres of $\mathrm{O}, \mathrm{H}$, and $\mathrm{Vi}$ antibodies bore no relation to susceptibility to infection or to its clinical severity. Illness occurred regardless of high antibody titres. Endotoxemia played no role in the pathogenesis of sustained disease. Parenterally and orally administered vaccine gave protection only against small numbers of ingested bacilli. The Widal reaction may be unspecific and appears during other salmonellar infections. ${ }^{230}$

In other studies, after ingesting live, attenuated $S$. typhosa as a vaccine, five of thirty volunteers were subsequently infected as compared with thirteen of twenty-six control subjects. ${ }^{231}$

As occurs when toilets are flushed, colon bacilli were emitted as aerosols during sewage processing. ${ }^{232}$

\section{Cholera}

Vibrios harboured in the gall-bladder diminish or disappear during passage through the bowel. They reappear in faeces during induced catharsis or by suppressing the normal flora with polymixin. ${ }^{233}$ Three of eighty-one cholera patients remained vibrio carriers for 50 to 331 days. ${ }^{233}$ The circumstance probably accounts for interepidemic reservoirs. ${ }^{233 a}$

The severity of cholera induced in thirty-five volunteers by ingested cultures ranged from inapparent infection to severe diarrhoea. Smaller numbers of vibrios were pathogenic when sodium bicarbonate was administered. Achlorhydria probably is conducive to disease ${ }^{234}$ as surmised for decades. ${ }^{235}$ Unless vomiting interferes, water and electrolytes given orally obviate much intravenous injection and equipment. ${ }^{236} \mathrm{~A}$ supplement of the May 1970 issue of the Journal of Infectious Diseases contains new information about cholera. Attention to epidemiology, vaccines, cholera toxin and antitoxin predominated. A book on the cholera problem was published. ${ }^{237}$

Small outbreaks in various parts of southern Asia, western and northern Africa and eastern Europe caused much apprehension elsewhere. Mass vaccination was recommended despite better methods of prevention. Single victims appeared in England and Japan, 107 in Israel and forty-five in Syria. ${ }^{238}$

Diphtheria still is prevalent in Iran ${ }^{239}$ and elsewhere. Exposure to infection by travellers and spread by rapid transit is ever-present. During 19 months, eighty-eight cases and three deaths occurred in 
Austin, Texas. ${ }^{240}$ Small outbreaks were observed in Chicago, Miami, and Phoenix since 1967. ${ }^{241}$

Plague. Mild attacks predominated in an outbreak in Vietnam. Bacilli persisted in buboes and throat during antimicrobic therapy. Carbuncles resembling anthrax pustules occurred. Antibody developed in about half of exposed but inapparently infected persons. ${ }^{242} \mathrm{~A}$ fatal case contracted from a rabbit occurred in November in Oregon. A book describes bubonic plague as it affected Britain. ${ }^{243}$ Yersinia pseudotuberculosis caused two instances of mesenteric adenitis and ileitis. Both patients recovered. ${ }^{244}$

\section{Tuberculosis}

In observations on BCG vaccination, vaccinees surprisingly had a slightly higher rate of tuberculosis than control subjects. ${ }^{245}$ (How will proponents regard that report?) Prophylaxis with isoniazid provided a substantial degree of protection. ${ }^{246}$ Polemic about the value of $B C G$ vaccination persists according to three letters to the Editor of the Annals of Internal Medicine of August, pp. 339-340. Primary resistance of $M$. tuberculosis to isoniazid is minimal in North America and Europe. Elsewhere in Africa and Asia from 21 to $70 \%$ of bacilli were said to be resistant. ${ }^{247}$

Two students contracted dermal tuberculosis while performing necropsies on tuberculous patients. Surgical excision of the lesions and chemotherapy were curative. ${ }^{248}$ Noncaseating granulomas were present in eight of thirty-two patients with pulmonic tuberculosis. ${ }^{249}$ A convenient dosage outline of eleven antituberculosis drugs and methods of therapy appeared in Clinical Notes on Respiratory Diseases, Vol. 9, No. 2.

Knowledge of atypical mycobacteria was reviewed by two authors. According to one, ${ }^{250}$ latent infections appeared to outnumber overt tuberculosis in the United States. In other reports atypical bacilli cause $2-5 \%$ of all acid-fast bacillary infections. Misdiagnosis and delayed therapy are deprecated.

Handling tropical fish and dolphins in aquariums resulted in persistent dermal infection with $\mathrm{Myco}$ bacterium marinum in four persons. ${ }^{251,}{ }^{252} \mathrm{~A}$ patient of mine who abraded his thumb on a rock in the Chesapeake bay has had a dry $2 \mathrm{~cm}$ ulcer for more than a year. Isoniazid reduced the lesion which again resumed after cessation of therapy. Excision and a skin-graft are contemplated.

\section{Coccal infections \\ Streptococci}

During a month, the source of thirteen postoperative haemolytic streptococcal wound infections was traced to an anaesthetist who carried the cocci in an anal verge. ${ }^{253}$ Dermal infections do not result in rheumatic fever. ${ }^{254},{ }^{255}$ Acute nephritis followed impetigo in four family members. ${ }^{256}$ Legally enforced detection and treatment of streptococcal pharyngitis begun in 1954 in Wyoming apparently lowered the isolation rate of haemolytic streptococci to $1.8 \% . \stackrel{\mathrm{C}}{\mathrm{c}}$

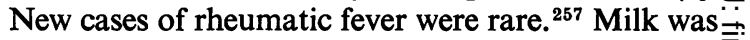
the source of infection of Group Chaemolytic streptococci which were nephritogenic in one-third ofo eighty-five patients with sore throat. ${ }^{258}$

\section{Carditis}

After the introduction of antimicrobic therapy, viridans streptococci, once the commonest cause, $\rightarrow$ have been replaced partly by staphylococci, entero-. cocci, Gram-negative bacilli and fungi. These mi- $\vec{\omega}$ crobes often are nosocomial in origin and drug- resistant. ${ }^{259}$ Congenital cardiac disease and alpha-e hemolytic streptococcal invasion accounted for re- 3 . peated attacks of endocarditis. Antimicrobic therapy succeeded in controlling relapses. ${ }^{260}$ Group Lir streptococci of animal origin, ${ }^{261}$ Serratia $^{262}$ and $\$$ anaerobes ${ }^{263}$ caused endocarditis. Serratia was said $\dot{\omega}_{\tilde{J}}^{\dot{\omega}}$ to form white colonies, but red variant ones prob- $N$ ably would appear after growth on agar. ${ }^{263 \mathrm{a}}$ 윽 Staphylococcus, Aspergillus, or Candida alone or mixed were invasive after valvulectomy. Anti- $\subseteq$ microbic therapy failed. ${ }^{264}$ After valve replacement $\overparen{D}$ during acute endocarditis, six of seventeen cases $\overrightarrow{0}$ ended fatally. The rest had no recurrent or persiste $\triangle$ infection. ${ }^{265}$

Echovirus 6 and 19, and Coxsackie type B virô․ are prominent causes of acute carditis and pleurodynia. ${ }^{266}$ Echovirus 4 probably caused myocarditis during a respiratory track infection. ${ }^{267}$

\section{Tonsillectomy}

After years of quiescence, controversy about tonsillectomy revived. In rheumatic children, the size of tonsils did not influence the incidence of recurrences when patients received antistreptococcal prophylaxis. In others, the size of tonsils was associated with increases in the rate of streptococcal infection and rheumatic recurrence. The collected data did not justify fully the reason for tonsillectomy but it was recommended prophylactically for un- 0 protected children who have major cardiac injury. ${ }^{268} \mathrm{~S}$ Extensive studies by Kaiser and others 30 years $\frac{7}{0}$ ago, ${ }^{269}$ failed to justify the operation to prevent rheumatic fever. Tonsillectomy with few exceptions $\mathcal{N}$ is questionable. ${ }^{270}$

\section{Meningitis}

Treatment of Group $\mathrm{C}$ meningococcosis was disappointing despite prompt penicillin injection. Among eighteen patients, systemic involvement de- $\stackrel{\mathbb{S}}{\rightarrow}$ veloped in twelve. Disseminated intravascular clotting caused death in shock of five. ${ }^{271}$ Perhaps a 'new' virulent strain was extant. Of sixteen adults with skull fractures, eight developed meningitis within 2 
weeks and four after more than a year, mostly with pneumococci. Six had recurrent attacks but only one died. ${ }^{272}$ In one case, $E$. coli was the cause. ${ }^{273}$ Two patients had meningococcal arthritis. ${ }^{274}$

According to two editorials in the April 1970 Journal of Infectious Diseases, neither sulphonamide drugs nor penicillin controlled meningococcosis. Experiments with antimeningococcal vaccines (immunogens) show promise. Immunization with a Group C polysaccharide preparation seemed to reduce the incidence of meningococcosis in Army recruits. Infections with group B cocci appeared in several immunized men. ${ }^{275}$ Studies with pneumococcal and $H$. influenzae antigens are underway. While serologic and other evidence indicated immunization, the real test will come after practical application.

Neonatal meningitis especially from Gramnegative bacilli occurred in twenty-five of 54,000 live births. Complications during pregnancy or delivery and of underweight infants were factors accounting for death in fifteen. ${ }^{276}$ Phlebitis, drug fever and unrelated infections prolonged fever in $9 \%$ of children with bacterial meningitis. ${ }^{277}$

\section{Pneumonia}

A committee of the American Thoracic Society formulated classifications of acute pulmonic infections. ${ }^{278}$ Essentially the same grouping appears in a forthcoming compend on pneumonia. ${ }^{279}$ Type 70 pneumococci resisted erythromycin but not tetracycline. Other high-numbered types resist tetracycline. ${ }^{280}$ Obviously, the need increases for serotype and sensitivity determinations to control therapy. ${ }^{281}$ Pneumococcemia caused death of four children with hemoglobinopathy. ${ }^{282}$ Intravascular clotting and peripheral gangrene also occurred. ${ }^{283}$ Meningococcus in the sputum of thirty pneumonic patients raised question as to its significance as a cause of pneumonia. 284

Pneumonia followed tracheostomy in seventeen of 139 patients, especially aged ones, usually within a week. Eleven died. ${ }^{285}$ Experiments support the clinical impression that prolonged oxygen therapy increases the susceptibility of the lung to infection. ${ }^{286}$

Pneumocystis carinii was the commonest cause of diffuse interstitial pneumonia in patients receiving immunosuppressive therapy ${ }^{287}$ and in children with cancer. Needle aspiration facilitated diagnosis. ${ }^{288}$ An outbreak of nineteen cases and forty inapparent infections were recorded. Cryptococcus, Aspergillus and Toxoplasma were other invaders. The onset of pneumonia was fulminant and often fatal. Treatment with pentamidine isothionate was recommended. ${ }^{289}$ During Myco. pneumoniae pneumonia, the microbe became resistant to erythromycin and to other antimicrobic drugs. The patient recovered anyway. ${ }^{290}$

\section{Gonorrhoea and syphilis}

Venereal diseases are pandemic and out of control. Gonorrhoea ranks first and syphilis fourth among reportable diseases in the U.S.A. ${ }^{291}$ Several factors are blamed: decline of moral values, permissiveness, contraceptive practice, over-reliance on prophylaxis and therapy, re-exposure and lack of effective immunity. ${ }^{292}$ According to national statistics, about one-half million cases of gonorrhoea and 18,000 of syphilis were reported in 1969. Probably more than four times as many failed registration. ${ }^{293}$ According to another view, $80 \%$ of venereal diseases are unreported. ${ }^{294}$

The risk of contracting gonorrhoea after exposure was $22 \%$ among Navy personnel on shore leave. ${ }^{295}$ After orogenital contact, a man had gonococcal pharyngitis followed by septicemia and arthritis. Erythromycin was curative. ${ }^{296}$ Gonococcal meningitis and shock were fatal in an infant. ${ }^{297}$ Instances of gonococcal perihepatitis ${ }^{298}$ and haemorrhagic bullae ${ }^{299}$ occurred. Several patients had papules, pustules and arthritis. ${ }^{300}$ Diagnostic and therapeutic procedures for the management of gonorrhoea were outlined. ${ }^{301}$ Gonococci and meningococci survive for days in a special medium for diagnostic purpose. $^{302}$

The increased incidence of syphilis heralds the resurgence of foetal infections. In one instance, massive penicillin therapy failed to influence a fatal course. Viable treponemes persisted in the tissue. ${ }^{303}$ Between 1958 and 1968 reported cases of syphilis increased $202 \%$; of congenital syphilis $168 \%{ }^{304}$

\section{Mycoses \\ Histoplasmosis}

Progressive disseminated disease ensued in twentyfive of 530 patients with histoplasmosis. The mortality after treatment with amphotericin was $7 \%$, without treatment $100 \% \%^{305}$ Amphotericin therapy failed in an English patient with disseminated disease probably acquired in Burma. ${ }^{306}$ Besides the usual features, peritonitis, ${ }^{307}$ hepatitis, endocarditis, meningitis, ${ }^{308}$ and exfoliative dermatitis ${ }^{309}$ occurred. Histoplasmosis declined by $86 \%$ among Michigan school children as a result of covering dusty areas and applying other measures. ${ }^{310}$ Blackbird and starling roosts are sources of infection. ${ }^{311}$

Darling who discovered histoplasmosis in 1906, probably was the first to describe Toxoplasma 2 years later. ${ }^{312}$ Darling also noted the morphologic resemblance of Histoplasma to Leishmania donovani for which he was searching.

\section{Coccidioidomycosis}

During an outing in Texas, nine of ten persons contracted coccidioidomycosis. The lungs were 
involved in seven and exanthems appeared in six. ${ }^{313}$ Eight children contracted coccidioidomycosis trom sandy soil in San Diego. Seven had pulmonic infiltration. Illness lasted 1-3 weeks. ${ }^{314}$ Pregnancy may activate benign coccidioidomycosis into fatal systemic dissemination. The foetus also may be involved. ${ }^{315}$ Many of 109 patients with chronic coccidioidomycosis had been suspected of having tuberculosis. Roentgenographic changes were unspecific. Amphotericin B is the drug of choice. ${ }^{316}$ Difficulties and delays in diagnosis involved nine victims of coccidioidal meningitis. The dermal test gave negative results in all. Diagnosis was made by the complement-fixation test and spinal fluid pleocytosis. ${ }^{317}$

Disseminated sporotrichosis is an increasingly important occurrence in debilitated patients. Four cases were described and twenty-seven others referred to. Amphotericin B is the therapeutic agent of choice. ${ }^{318}$ An air-conditioning system contaminated with an actinomycete induced hypersensitivity and granulomatous interstitial pneumonia in office workers. ${ }^{319}$ Five of twenty-two surgical patients nourished intravenously developed Candida albicans (monilia) septicemia. Two died. ${ }^{320}$ Epithelial tissue unable to combat superficial mycotic infections because of immunologic deficiency and its correction was discussed. ${ }^{321}$

The value of skin testing with fungal antigens was questioned. The high rate of false negative reactions, the thousands of healthy persons who react and the interference with serologic procedures are well known. Tests with blastomycin and histoplasmin are not needed when overt disease is suspected. Coccidioidin should only be used after careful evaluation. Simultaneous application of several antigens was condemned. ${ }^{322}$

\section{Opportunistic invaders}

The length of this section reflects the growing hazard of opportunistic and nosocomial infections. A review summarized the problem. ${ }^{323}$ Anaerobic bacteria were present in $\mathbf{4 8 2}$ of 1223 specimens of lesions; in pure culture in $21 \%$. Bacteroides was the commonest. ${ }^{324}$ Bacteroides septicemia developed during incomplete abortion in $50 \%$ of 111 women. All survived regardless of antimicrobic therapy. ${ }^{325}$ Bacteremia in thirty-five patients $(0.2 \%$ of 25,000 blood-cultures) caused death from shock in twelve. Only one victim less than 40 years old died. Jaundice, hepatic abscess and pylephlebitis were commoner than in other Gram-negative bacillary infections. ${ }^{326}$ In another study, thirty-four patients were bacteremic chiefly after enteric surgery. ${ }^{327}$ Six per cent of patients with gastrointestinal, hepatic or urinary tract disease had bacteremia with more than one microbe. Endocarditis developed in three. ${ }^{328}$

In a hospital, Type 24 was the most frequent endemic strain of Klebsiella. It was often associated with urinary catheterization. Type 26 was endemico in the nursery. Nearly all strains were sensitive to gentamicin. ${ }^{329}$ Pseudomonal infections involved $26 \%$ of eighty-seven leukaemic patients. While in a hospi-s tal $54 \%$ became carriers. ${ }^{330}$ Injection of a contamio nated muscle relaxant caused nonfatal Gram $\overline{\bar{\sigma}}$ negative bacillary infection and shock in five surgica $\bar{s}$. patients in one day. ${ }^{331}$ Another nosocomial out $\mathbb{\Phi}^{\mathbb{D}}$ break of Serratia infection from contaminatedn inhalation apparatus was described. 374 patients were involved in a 10-month period. ${ }^{332}$ Serratio was discussed in two papers in the Journal of the $\vec{\omega}$ American Medical Association of 21 December Bizio applied the name Serratia in 1823.

B. bronchoseptica, Ps. multophilia, $H$. vaginicola, $M$. polymorpha, heretofore disregarded as sapro- $\rightarrow$ phytes, occasionally are incidental invaders particu-r larly in hospital patients. ${ }^{333}$ Infections of the feet,,$\stackrel{\infty}{\circ}$ lungs, kidneys, gallbladder, and skin in that order $\omega_{\omega}^{\omega}$ affected $10 \%$ of 640 diabetic patients. ${ }^{334}$

Staphylococcus aureus sepsis complicated six cases? of arteriovenous fistula maintained by hemodialysis. $P s$. aeruginosa caused one. There was no relation $\subseteq$ between local infection and sepsis. ${ }^{335}$ Staphylococcus ${ }^{\circ}$ albus bacteremia and renal infection complicates $\vec{c}$ ventriculo-atrial shunts in three patients. Impro\&- ment followed the removal of the shunts. Fluorescent micrography showed immunoglobulin in glomertit suggesting an immune reaction as the cause. ${ }^{336} \mathrm{No}$ reports of invasion of Micrococcus tetragenus, a common saprophyte, were encountered. The coccus is easily mistaken for staphylococci.

Antimicrobic therapy has allowed many instances $\overrightarrow{\bar{B}}$ of acute subphrenic abscess to become chronic. ${ }^{337} 3$ The danger of serious infections, haemorrhage and intravascular clotting after splenectomy in children was re-emphasized. ${ }^{\mathbf{3} 8}$

Herpes hominis, rubella and cytomegaloviruses which occasionally infect the foetus are teratogenic. Other invaders are the viruses of rubeola, equine encephalitis, vaccinia, variola, polio, hepatitis and Coxsackie disease. These are invasive oftener than 0 believed especially in disadvantaged persons. About $5 \%$ of pregnancies are complicated by viral infections, 을 chiefly colds, herpes simplex and viral dysentery. ${ }^{339}$

Routine blood cultures from four men who had N no contact with animals, but had an underlying $N$ chronic condition, disclosed Vibrio fetus septicemia స్ during a 4-year period in Boston. ${ }^{340}$ Probably fewer $\sigma$ than $1 \%$ of Vibrio fetus infections are recognized. So far about seventy-four case reports have been $\frac{0}{\square}$ published. The infection is widespread and affects $\stackrel{D}{\rightarrow}$ infants, pregnant women and particularly aged and decrepit men. Eight cases were observed in a 30 month period in New York City. Tetracycline therapy was beneficial but relapses followed. ${ }^{341}$ 
Candida infected a tricuspid valve after an aged man was treated with antimicrobic drugs for pulmonary disease. ${ }^{342}$ Severe diabetes predisposes to fatal rhinocerebral phycomycosis. ${ }^{343}$ Torulopsis glabrata as an opportunistic invader infected thirtyseven patients in a 16 -month period. ${ }^{344}$

'Septic shock' is a common host-response to Gram-negative and Gram-positive bacillary and coccal infections ${ }^{345}$ and probably to viral infections.

\section{Relation of complement to infection}

Repeated infections involved a patient whose measurable immunity factors were normal except for deficiency of C3 serum complement component. The addition of $\mathrm{C} 3$ to his serum did not restore haemolytic activity and its lack may not be entirely accountable for susceptibility to infection..$^{346}$ In another patient susceptible to infections, deficiency of $\mathrm{C5}$ as a heritable trait impaired phagocytic activity. Addition of C5 restored phagocytic ability. ${ }^{347}$ The matter is of interest in regard to the relation of serum complement components to hypothetical opsonins and their role in controlling infections. ${ }^{348}$ The matter was discussed editorially. ${ }^{349}$ Specific nonheritable deficiencies of various $\gamma$-globulins accounted for recurrent pyogenic infections. Replacement therapy was preventive. ${ }^{350}$

\section{Infections acquired from mammals, birds, and fish}

Chapman cited histoplasmosis, coccidioidomycosis, cryptococcosis, toxoplasmosis, rickettsioses, catscratch disease, avian and atypical tuberculosis, relapsing fever, rabies and plague as zoonoses. ${ }^{351}$ Salmonellosis, anthrax, glanders, orf, yellow fever, tularemia and others could be added to the list. Increasing travel, out-door living and camping favour greater contact with sources of infection. For example, thirty-one cases of plague were reported from the western U.S.A. between 1965 and 1969. A fatal case was contracted from a wild rabbit in Oregon in 1970.

Two reports dealt with 316 Pasteurella multocida infections. Bites or scratches from animals caused 180 cases and 136 victims had no known animal contact. The respiratory tract, abdominal organs, extremities, central nervous system and other areas were affected in that order ${ }^{352}$ Dermal infection with Myco. marinum acquired from fish was mentioned elsewhere. ${ }^{251}$

Sixteen necropsy studies of melioidosis disclosed a variety of widely scattered lesions containing the bacilli. Granulomatous lesions confined to a single organ characterized chronic disease. Like glanders, melioidosis affects cattle, pigs and sheep in Asia, Australia and the Dutch Antilles. ${ }^{353}$

Hospital food, especially meat and poultry contained large numbers of $E$. coli able to invade patients. Antimicrobic prophylaxis for animals and birds may cause the emergence of resistant bacilli which in turn may cause resistant infections in man. ${ }^{354}$ A book describes food-borne viral, bacterial and vibrial infections. ${ }^{355}$ Mammalian ecology has importance in the epidemiology of zoonoses of which 150 are known. ${ }^{355 a}$

Rickettsia canada a newly discovered member of the typhus group caused severe febrile disease in four patients. Clinically it resembled Rocky Mountain spotted fever. ${ }^{356}$ Rocky Mountain spotted fever was acquired by inhalation in a vaccinated laboratory technician. $^{357}$ Cat fleas were vectors of murine typhus in Texas. ${ }^{358}$ The July 1970 issue of the Archives of Environmental Health contains three papers about $\mathbf{Q}$ fever in Milwaukee. The incidence has increased among cattle since 1957. Volunteers who drank naturally infected milk showed no evidence of infection. Since 1955, evidence of $Q$ fever was present in 2428 persons in the city.

Carrithers summarized the historical development of knowledge concerning cat-scratch disease. ${ }^{359}$ As might have been expected, relatives of two exotic viruses exist in the U.S.A. Cache Valley virus, a member of the Bunyamwera group, was present in mosquitoes in Viginia and antibody was found in domestic animals and man. ${ }^{360}$ Rats in Florida harboured Tamiami virus which is related to Tacaribe viruses. ${ }^{361}$ Man may be a source of fowl plague for fowl. ${ }^{362}$

Cutaneous leishmaniasis is hyperendemic near Jericho. During a month, $50 \%$ of newly arrived men were infected. A wild rodent is the source and phlebotomus the vector. ${ }^{363}$ Dermal myiasis caused by a rabbit bot fly occurred in Connecticut. ${ }^{364}$ Taenia multiceps, a dog tapeworm, probably transmitted by a rabbit, caused a fatal intracranial cyst in a child. ${ }^{365}$ Migration of a proglottid of Taenia into the uterus caused bleeding. ${ }^{366}$

The piroplasma Babesia causes world-wide, tickborne, haemolytic disease of many wild and domestic animals. Four splenectomized patients were reported from Yugoslavia, California and Ireland. It is easily mistaken for malaria. Other instances probably have not been recognized. ${ }^{367}$

Newly recognized Toxocara harboured by dogs and cats caused ocular, hepatic, pulmonic, myocardial and other lesions in man. Two per cent of Britons were said to be infected. ${ }^{368}$ Serologically, toxocara and toxoplasma are unrelated. ${ }^{369}$ Toxoplasmic encephalitis occurred in three adults. ${ }^{370}$

An outbreak of leptospirosis involved about $4 \%$ of the population of an Israeli farming community. Twenty-nine victims were studied but probably many more were mildly or inapparently infected. ${ }^{371}$ During epizootics of feline pneumonia caused by one of the Bedsonia, infection transmitted to man caused 
corneal ulcers. ${ }^{372}$ Infection with Fasciola hepatica (liver fluke), probably contracted from watercress in sheep and cattle raising districts, by forty-four English patients responded to therapy with emetine and chloroquine. ${ }^{373}$ Enteric coccidiosis present in six patients may be a cause of malabsorption diarrhoea and steatorrhoea. Therapy was ineffective. ${ }^{374}$

Gnathostomiasis, indigenous to Southeast Asia, occurred in two Mexicans. Larvas inhabited the abdominal wall in one, the eye in the other. ${ }^{375}$

\section{Miscellaneous items}

\section{Urinary tract infection}

Kunin summarized information gained in a 10year study of bacteriuria in girls. Bacteriuria occurs in more than $5 \%$ and often is symptomless. The risk of infection is enhanced by marriage and pregnancy. Serologic typing of $E$. coli aids in distinguishing between relapses and recurrent reinfection. Ampicillin was no more effective therapeutically than nitrofurantoin and sulfonamide drugs. Bacteriuria requires treatment to reduce morbidity. Vesicoureteral reflux occurs in about $20 \%$ of girls, decreases with age and often resolves spontaneously. Surgical correction seldom is necessary. ${ }^{376}$ Closed sterile drainage of the urinary bladder by a new apparatus obviated cystitis in twenty-eight of fifty-one patients. Ascending infection occurred in others through the lumen of the tube. ${ }^{377}$

Immunologic features, serious consequences and the therapy of malaria were discussed at a conference. ${ }^{378}$ Fifteen years after eradicating malaria on an island, $1 \%$ of population still had antibody. ${ }^{379} \mathrm{~A}$ purified fraction of $\boldsymbol{P l}$. berghei used as an immunogen prevented parasitemia, anemia and death of mice inoculated with the same strain..$^{380}$ Returnees from Vietnam accounted for 3800 new cases of malaria in the U.S.A. in 1969.

Four persons contracted fatal amoebic meningoencephalitis in public swimming places in Virginia. Antimicrobic therapy failed. ${ }^{381}$ The first observed fatal case occurred in Britain. ${ }^{382}$ The latex agglutination test for diagnosis of rheumatoid arthritis, gave positive results during invasive amoebiasis. ${ }^{383}$ Metronidazole promises to be effective in treating amoebic dystentery. ${ }^{384}$ Of sixty-five hepatic abscesses, fiftyeight were pyogenic in origin; four were amoebic; two were mycotic and one was ecchinococcal. ${ }^{385}$

Ten bathers in a Puerto Rican river contracted schistosomiasis. One was symptomless, six had mild fever and diarrhoea, and seven had hepato- or splenomegaly and were severely sick. All had eosinophilia. All recovered without chemotherapy. ${ }^{386}$ The event is reminiscent of leptospirosis involving seven bathers in a Pennsylvania stream I described in 1941. Filtration of portal blood removes the flukes from victims of schistosomiasis. ${ }^{387}$
Among 178 Samoan immigrants, $14 \%$ had microfilaremia after 8 years' residence in the U.S.A. The danger of spread is unlikely. ${ }^{388}$

The matter of autogenous vaccines was reviewed. They may be dubious disensitizers or act by stimulating specific antibodies anamnestically. ${ }^{389}$ Multi-O valent vaccine containing two strains of staphylo-흐 cocci, six types of Pseudomonas and staphylococcal $\frac{\bar{m}}{5}$ toxoid failed to affect the death-rate of thirty-nine $\underset{\complement}{\mathbb{\Phi}}$ burned patients. ${ }^{390}$ The general cost of immunizing infants was estimated at $\$ 42$ per child. ${ }^{391}$

Persons who handle the proteolytic enzymes of $\vec{\circ}$ $B$. subtilis occasionally suffer severe asthmatic $\overrightarrow{\vec{\omega}}$ attacks. In forty-six hamsters, aerosol inhalation of ${ }^{\text {D }}$ the enzymes caused pulmonic haemorrhages andర death in eight. ${ }^{392}$ Allergy to intestinal parasites was 3 . proposed as a cause of asthma. ${ }^{393}$

Because of sanitary and housing deficiency, the ${ }^{2} \mathrm{r}$ health status of Navaho Amerinds has not advanced $+\infty$ for 30 years. Tuberculosis is seven times the national rate. Trachoma, gonorrhoea, syphilis, dysentery, $N$ measles and chickenpox are three to seven times as을 common. ${ }^{394}$

The United States Government stopped work on $\bar{\subseteq}$ agents for biologic warfare. Besides aggressive $\overparen{乛}$ psychologic influence and affecting local groups, the $\overrightarrow{0}$ chance of inflicting significant epidemics is meage्ष्?

\section{References}

1. MANDELL, G.L. et al. (1970) Enterococcal endocarditis Archives of Internal Medicine, 125, 258.

2. Mandell, G.L., Lindsey, E. \& Hook, E.H. (1970) ڤొ Synergism of vancomycin and streptomycin for entero- $\mathbb{D}$ cocci. American Journal of Medical Sciences, 259, 346.

3. RUTHERFORD, W.H. et al. (1970) Antibiotics in surgical $\overrightarrow{\overline{0}}$ treatment of septic lesions. Lancet, i, 1077.

4. Parker, M.T. \& HewitT, J.H. (1970) Methicillin resistance in Staphylococcus aureus. Lancet, i, 800.

5. ToAlA, P. et al. (1969) Susceptibility of Group Dstreptococci (enterococcus) to 21 antibiotics in vitro, 음 with special reference to species difference. American? Journal of Medical Sciences, 258, 416.

6. RifF, L., OleXY, V. \& JACKSON, G.G. (1970) Gentamicin treatment of serious Gram-negative bacillary infections. Program of American College of Physicians, $\frac{2}{3}$ April, 104.

7. SAвATH, L.D. et al. (1970) Increasing the usefulness of $\frac{\text { 음 }}{3}$ antibiotics: Treatment of infections caused by Gram- $D$ negative bacilli. Clinical Pharmacology and Thera-으․ peutics, 11, 161.

8. WeINSTEIN, L. \& KaPLAN, F. (1970) The cephalosporins. N Microbiological, chemical, and pharmacological pro- $N$ perties and use in chemotherapy of infection. Annals of Internal Medicine, 72, 729.

9. PAGE, J. et al. (1970) Treatment of soft tissue infection $\sigma$ with cephalexin. Journal of the American Medical Association, 211, 1837.

10. Kunin, C.M. \& Finkelberg, Z. (1970) Oral cephalexin and ampicillin. Antimicrobic activity, recovery in urine,,+ and persistence in blood; of uremic patients. Annals of Internal Medicine, 72, 349.

11. Pines, A. et al. (1970) Treatment of severe pseudomonas $\stackrel{\vec{Q}}{\mathbb{Q}}$ infections of bronchi. British Medical Journal, 1, 663. $\frac{}{\mathbb{D}}$ 
12. Phair, J.P. et al. (1970) Carbenicillin treatment of Pseudomonas pulmonary infections. American Journal of Diseases of Children, 120, 22.

13. Meyers, B.R., SAbbaj, J. \& Weinstein, L. (1970) Bacteriological, pharmacological, and clinical studies of carbenicillin. Archives of Internal Medicine, 125, 682.

14. Carbenicillin (1970) Medical Letter, 12, 41.

15. Hoffman, T.A. \& Bullock, W.E. (1970) Carbenicillin therapy of Pseudomonas and other Gram-negative bacillary infections. Annals of Internal Medicine, 73, 165.

16. Marks, M.I. \& Eickhoff, T.C. (1970) Carbenicillin: A clinical and laboratory evaluation. Annals of Internal Medicine, 73, 179.

17. Bodner, S.J., Koenig, M.G. \& Goodman, J.S. (1970) Bacteremic bacteroides infections. Annals of Internal Medicine, 73, 537

18. Bulger, R.J., Larson, E. \& Sherris, J.C. (1970) Decreased incidence of resistance to antimicrobial agents among Escherichia coli and Klebsiella-enterobacter. Annals of Internal Medicine, 72, 65.

19. NIIT, Y. et al. Resistance of Mycoplasma pneumoniae to erythromycin and other antibiotics. Journal of Pediatrics, 76, 438.

20. The choice and uses of the erythromycins. (1970) Medical Letter, 12, 35.

21. Tests of rifampin confirm efficacy against tuberculosis. (1970) Journal of the American Medical Association, 212, 1787.

22. Val-Spinoza, A. et al. (1970) Rifampin in the treatment of drug resistant Mycobacterium tuberculosis infections. Lancet, ii, 616.

23. ReEs, R.J.W. et al. (1970) Experimental and clinical studies on rifampicin in treatment of leprosy. British Medical Journal, 1, 89.

24. Antiviral action of rifampin. Editorial (1970) Lancet, i, 399.

25. Devine, L.F. et al. (1970) Rifampin. Levels in serum and saliva and effect on the meningococcal carrier state. Journal of the American Medical Association, 214, 1055.

26. Mohr, J.A., RhoAdes, E.R. \& Muchmore, H.G. (1970) Actinomycosis treated with lincomycin. Journal of the American Medical Association, 212, 2261.

27. Clindamycin (cleocin) (1970). Medical Letter, $12,85$.

28. Herrell, W.E. (1970) History of the development of antibiotics. Clinical Medicine, 77, 10.

29. Somkuti, G.A. \& WALter, M.M. (1970) Antimicrobial polypeptide synthesized by Mucor pusillus NRRL 2543. Proceedings of the Society for Experimental Biology and Medicine, 133, 780.

30. Kyle, R.A. \& Linman, J.W. (1970) Gingivitis and chronic idiopathic neutropenia: Report of two cases. Proceedings of the Staff Meetings of the Mayo Clinic, 45, 494.

31. Howie, J.G.R. \& Clark, G.A. (1970) Double blind trail of early dimethylchlortetracycline in minor respiratory illness in general practice. Lancet, ii, 1199.

32. SChECKLER, W.E. \& BenNetT, J.V. (1970) Antibiotic usage in seven community hospitals. Journal of the American Medical Association, 213, 264.

33. Finland, M. (1970) Changing ecology of bacterial infections related to antibacterial therapy. Journal of Infectious Diseases, 122, 419.

34. Price, D.J.E. \& Sleigh, J.D. (1970) Control of infection due to Klebsiella aerogenes in a neurosurgical unit by withdrawal of all antibiotics. Lancet, ii, 1213.

35. Weinstein, L. (1970) Type B haemophilus influenzae infections in adults. New England Journal of Medicine, 282, 221.
36. Davia, J.E., Siemsen, A.W. \& Anderson, R.W. (1970) Uremia, deafness, and paralysis due to irrigating antibiotic solutions. Archives of Internal Medicine, 125, 135.

37. MCQuillen, M.P. (1970) Hazard from antibiotics in myasthenia gravis. Annals of Internal Medicine, 37, 487.

38. LAvy, S. \& Stein, H. (1970) Convulsions in septicemic patients treated by penicillin. Archives of Surgery, 100, 225.

39. Willis, R.R. \& PhaIR, J.P. (1970) Anaphylactoid reactions with oral use of ampicillin. Archives of Internal Medicine, 125, 312.

40. Weary, P.E., Cole, J.W. \& Hickham, L.H. (1970) Eruptions from ampicillin in patients with infectious mononucleosis. Archives of Dermatology, 101, 86.

41. KNIRSCH, A.K. \& Gralla, E.J. (1970) Abnormal serum transaminase levels after parenteral ampicillin and carbenicillin administration. New England Journal of Medicine, 282, 1081.

42. Kurtzman, N.A., Rogers, P.W. \& Harter, H.R. (1970) Neurotoxic reaction to penicillin and carbenicillin. Journal of the American Medical Association, 214, 1320.

43. Levine, P.H., Regelson, W. \& Holland, J.F. (1970) Chloramphenicol associated encephalopathy. Clinical Pharmacology and Therapeutics, 11, 194.

44. КосH-WeSER, J. et al. (1970) Adverse effects of sodium colistimethate. Annals of Internal Medicine, 72, 857.

45. BeRK, D.P. \& ChALmERs, T. (1970) Deafness complicating antibiotic therapy of hepatic encephalopathy. Annals of Internal Medicine, 73, 393.

46. Meyers, R.M. (1970) Ototoxic effects of gentamicin. Archives of Otolaryngology, 92, 160.

47. AdLer, J.L. et al. (1970) Nosocomial colonization with kanamycin-resistant Klebsiella pneumoniae types 2 and 11 , in a premature nursery. Journal of Pediatrics, 77, 376.

48. Fass, R.J., Perkins, R.L. \& Saslow, S. (1970) Positive direct Coomb's test associated with cephaloridin therapy. Journal of the American Medical Association, 2.12, 121.

49. BenNer, E.J. (1970) Cephaloridine and the kidneys. Journal of Infectious Diseases, 122, 104.

50. LEEs, A.W. et al. (1970) Jaundice after Rifampin. British Journal of Diseases of the Chest, 64, 90.

51. Blajchman, M.A. et al. (1970) Rifampin-induced immune thrombocytopenia. British Medical Journal, 3, 24.

52. Martin, C.E. \& Arthaud, J.B. (1970) Hepatitis after isoniazid administration. New England Journal of Medicine, 282, 433.

53. O'Toole, R.D. et al. (1970) An outbreak of methicillinresistant Staphylococcus aureus infection. Journal of the American Medical Association, 213, 257.

54. Lincoln, K., Lidin-Janson, G. \& Winberg, J. (1970) Resistant urinary infections resulting from changes in resistance pattern of fecal flora induced by sulfonamide and hospital environment. British Medical Journal, 3, 305.

55. Liability for penicillin reactions. (1970) Journal of the American Medical Association, 212, 2015.

56. Mogabgab, W.J. \& Leiderman, E. (1970) Immunogenicity of 1967 polyvalent and 1968 Hong Kong influenza viruses. Journal of the American Medical Association, 211, 1672.

57. Philip, R.N. et al. (1969) Epidemiologic studies on influenza in familial and general population groups, 1951-56. American Journal of Epidemiology, 90, 471, 483.

58. SMITH, T.J. et al. (1970) Hong Kong influenza in U.S. military airmen in Thailand. American Journal of Tropical Medicine and Hygiene, 19, 866. 
59. Clark, P.S. et al. (1970) An influenza B epidemic within a remote Alaska community. Journal of the American Medical Association, 214, 507.

60. Stuart-Harris, C.H. (1970) Pandemic influenza: An unresolved problem in prevention. Journal of Infectious Diseases, 122, 108.

61. Waldman, R.H. et al. (1970) Influenza IgA antibody response following aerosol administration of inactivated viruses. American Journal of Epidemiology, 91, 575.

62. Rosenberg, G.A. (1970) Meningoencephalitis following influenza vaccination. New England Journal of Medicine, 283, 1209.

63. Bloomfield, S.S., Gaffney, T.E. \& Schiff, G.M. (1970) A design for the evaluation of antiviral drugs in human influenza. American Journal of Epidemiology, 91, 568.

64. Smorodintsev, A.A. et al. (1970) Evaluation of Amantadine in artificially induced A2 and B influenza. Journal of the American Medical Association, 213, 1448.

65. Togo, Y. et al. (1970) Evaluation of therapeutic efficacy of amantadine in patients with naturally occurring A2 influenza. Journal of the American Medical Association, 211, 1149.

66. Middleton, P.J., Alexander, R.M. \& Szymanski, M.T. (1970) Severe myositis during recovery from influenza. Lancet, ii, 533.

67. Simon, N.M., Rovner, R.N. \& Berlin, B.S. (1970) Acute myoglobinuria associated with Type A2 (Hong Kong influenza). Journal of the American Medical Association, 212, 1704.

68. LindSAY, M.I. et al. (1970) Hong Kong influenza. Journal of the American Medical Association, 214, 1825.

69. HerrmanN, E.C. \& HABEL, K.A. (1970) Experiences in laboratory diagnosis of parainfluenza viruses in routine medical practice. Proceedings of the Staff Meetings of the Mayo Clinic, 45, 177.

70. Zollar, L.M. \& Mufson, M.A. (1970) Acute parotitis associated with parainfluenza 3 virus. American Journal of Diseases of Children, 119, 147.

71. Wigley, F.M., Fruchtman, M.H. \& Waldman, R.H. (1971) Aerosol immunization of humans with inactivated parainfluenza 2 vaccine. New England Journal of Medicine, 283, 1250.

72. BRANDT, C.D. et al. (1969) Infections in 18000 infants and children in a controlled study of respiratory tract disease. American Journal of Epidemiology, 90, 484.

73. Blacklow, N.R. et al. (1969) Observations on two new adenovirus serotypes with unusual antigenic characteristics. American Journal of Epidemiology, 90, 501.

74. Griffin, J.P. \& Greenberg, B.H. (1970) Live and inactivated adenovirus vaccines. Archives of Internal Medicine, 125, 981.

75. Lennette, E.H., Chin, J. \& Magoffin, R.L. (1970) Studies on respiratory disease at Fort Ord, Calif., 1957-68. Archives of Environmental Health, 21, 321.

76. Rose, H.M., LAmson, T.H. \& BuesCher, E.L. (1970) Adenovirus infections in military recruits. Archives of Environmental Health, 21, 356.

77. Wegman, D.H., Guinee, V.F. \& Millian, S.J. (1970) Epidemic keratoconjunctivitis. American Journal of Public Health and the Nation's Health, 60, 1230.

78. ConNOR, J.D. (1970) Evidence for an etiologic role of adenoviral infection in pertussis syndrome. New England Journal of Medicine, 283, 390.

79. SChieble, J.H., LenNette, E.H. \& FoX, V.L. (1970) Antigenic variation of rhinovirus type 22. Proceedings of the Society for Experimental Biology and Medicine, 133, 329.
80. Phillips, C.A., Melnick, J.L. \& Sullivan, L. (1970) Characterization of four new rhinovirus serotypes. Proceedings of the Society for Experimental Biology and Medicine, 134, 933.

81. URQUHART, G.E.D. \& ScotT, E.J. (1970) Rhinoviremia. British Medical Journal, 4, 28.

82. Hilleman, M.R. (1970) Double-stranded RNAs (Poly I : C) in the prevention of viral infections. Archives of Internal Medicine, 126, 109.

83. Tyrrell, D.A.J. (1970) Hunting the common cold $\frac{\bar{\omega}}{\partial}$ viruses by some new methods. Journal of Infectious $\mathbb{\Phi}$ Diseases, 121, 561.

84. McIntosh, K. et al. (1970) Seroepidemiologic studies (\$) of coronavirus infection in adults and children. $\vec{\circ}$ American Journal of Epidemiology, 91, 585.

85. Cavallero, J.J. \& Monto, A.S. (1970) Community- $\overrightarrow{\vec{\omega}}$ wide outbreak of infection with a $229 \mathrm{E}$-like coronavirus $\omega$ in Tecumseh, Michigan. Journal of Infectious Diseases, 122, 272.

86. Gardner, P.S., McQuillan, J. \& Court, S.D.M. (1970) Speculation on pathogenesis in death from $A$ respiratory syncytial virus infection. British Medical ir Journal, 1, 327.

87. Neligan, G.A. et al. (1970) Respiratory syncytial virus infection of newborn. British Medical Journal, 3, 146. $\omega$

88. Hable, K.A., O'Conell, E.J. \& HerrmanN. E.C. N (1970) Group B coxsackieviruses as respiratory viruses. 음 Proceedings of the Staff Meetings of the Mayo Clinic, 45, 170.

89. Couch, R.B. et al. (1970) Airborne transmission of respiratory infection with coxsackievirus A type 21 .

American Journal of Epidemiology, 91, 78 .
90. CHANOCK, R.M. (1970) Control of acute mycoplasm $8 \overrightarrow{1} \vec{\theta}$ and viral tract disease. Science, 169, 248.

91. Blumberg, B.S. et al. (1970) Australia antigen amd hepatitis. New England Journal of Medicine, 283, 348.

92. ZuCKerman, A.J. (1970) Serum hepatitis and the Australia antigen. British Journal of Haematology, 19, $1 . \bar{\partial}$

93. More about Australia antigen and hepatitis. (1970) Editorial Lancet, ii, 347.

94. GoCKE, D.J. et al. (1970) Association between polyarteritis and Australia antigen. Lancet, ii, 1149.

95. KRUgman, S. \& Giles, J. (1970) Viral hepatitis. New light on an old disease. Journal of the American Medical Association, 212, 1019.

96. MatThews, J.D. \& MACKAY, I.R. (1970) Australia antigen in chronic hepatitis in Australia. British Medical Journal, 1, 259.

96a. Prince, A.M. et al. (1970) Immunologic distinction $\overline{0}$ between infectious and serum hepatitis. New England Journal of Medicine, 282, 987.

97. Chang, L.W. \& O'Brien, T.F. (1970) Australia antigen serology in the Holy Cross football team outbreak. Lancet, ii, 59.

98. KROHN, K. et al. (1970) Electron microscopical and $\underset{D}{ }$ immunological observations on the serum-hepatitis (S.H.) antigen in primary biliary cirrhosis. Lancet, ii, $\mathrm{N}$ 379.

99. Dane, D.S., Cameron, C.H. \& Briggs, M. (1970) Virus- N like particles in serum of patients with Australia-O antigen-associated hepatitis. Lancet, i, 695.

100. Krugman, S. (1970) Etiology of viral hepatitis Hospital Practice, 5, 45.

101. BARKER, L.F. et al. (1970) Transmission of serum hepa-c titis. Journal of the American Medical Association, 211, 1509.

102. Gocke, D.J., Greenberg, H.B. \& Kavey, N.B. (1970) Correlation of Australia antigen with post-transfusion $\frac{O}{9}$ hepatitis. Journal of the American Medical Association, $\stackrel{\mathbb{Q}}{\mathbb{Q}}$ 212, 877 . 
103. Lorenz, D. et al. (1970) Hepatitis in the marmoset, Sanguinus mystax. Proceedings of the Society for Experimental Biology and Medicine, 135, 348.

104. BogGS, J.D. et al. (1970) Viral hepatitis. Clinical and tissue culture studies. Journal of the American Medical Association, 214, 1041.

105. Vischer, T.L. (1970) Australia antigen and autoantibodies in chronic hepatitis. British Medical Journal, 2, 695.

106. FArrow, L.J. et al. (1970) Autoantibodies and the hepatitis-associated antigen in acute infective hepatitis. British Medical Journal, 2, 693.

107. Del Prete, S. et al. (1970) Detection of a new serumantigen in three epidemics of short-incubation hepatitis. Lancet, ii, 579.

108. Prince, A.M. (1970) Prevalence of serum-hepatitisrelated antigen (SH) in different geographic regions. American Journal of Tropical Medicine and Hygiene, 19, 872.

109. Lous, P., Olesen, H. \& Skinhø. P. (1970) Hepatitisassociated (AU/SH) antigen determination in 10,000 patients in a Copenhagen hospital. Lancet, i, 119.

110. NAS-NRC tells of status of hepatitis screening tests. (1970) Journal of the American Medical Association, 211, 907.

111. Viral hepatitis. (1970) Clinical Staff Conference, N.I.H Annals of Internal Medicine, 72, 257.

112. Tullis, J.L. et al. (1970) Incidence of post-transfusion hepatitis in previously frozen blood. Journal of the American Medical Association, 214, 719.

113. Saravis, C.A., Trey, C. \& Grady, G.F. (1970) Rapid screening test for detecting hepatitis-associated antigen. Science, 169, 298.

114. Prince, A.M. \& Burke, K. (1970) Serum hepatitis antigen (SH): Rapid detection by high voltage immunoelectroosmophoresis. Science, 169, 593.

115. Beebe, G.W. \& Simon, A.H. (1970) Cirrhosis of the liver following viral hepatitis, a twenty-year mortality follow-up. American Journal of Epidemiology, 92, 279,

116. Fears about rubella vaccine fade after the first year. (1970) Journal of the American Medical Association 213, 23.

117. Halstead, S.B., Char, D.F.B. \& Diwan, A.R. (1970) Evaluation of three rubella vaccines in adult women. Journal of the American Medical Association, 211, 991.

118. Phillips, C.A. et al. (1970) Intrauterine rubella infection following immunization with rubella vaccine. Journal of the American Medical Association, 213, 624.

119. Furukawa, T. et al. (1970) Rubella vaccination during an epidemic. Journal of the American Medical Association, 213, 987.

120. Chang, Te-Wen, Des Rosiers, S. \& Weinstein, L. (1970) Clinical and serologic studies of an outbreak of rubella in a vaccinated population. New England Journal of Medicine, 283, 246.

121. HorstmanN, D.M. et al. (1970) Rubella: reinfection of vaccinated and naturally immune persons exposed in an epidemic. New England Journal of Medicine, 283, 771.

122. Rubella vaccine reconsidered. (1970) Medical Letter, $12,91$.

123. Studies of the effect of immunoglobulin on rubella in pregnancy (1970) British Medical Journal, 2, 497.

124. Lefkowitz, L.B. et al. (1970) A controlled family study of live, attenuated rubella-virus vaccine. New England Journal of Medicine, 283, 229.

125. VeRONELLI, J.A. (1970) An open community trial of live rubella vaccines. Journal of the American Medical Association, 213, 1829.

126. Rubella virus vaccine. Recommendation of the advisory conımittee on immunization practices, U.S. Public
Health Service. (1970) Annals of Internal Medicine, 73, 779 .

127. LANE, J.M. et al. (1970) Deaths attributed to smallpox vaccination, 1959-66, and 1968. Journal of the American Medical Association, 212, 441.

128. LANE, J.M. et al (1970) Complications of smallpox vaccination, 1968: Results of ten statewide surveys. Journal of Infectious Diseases, 122, 303.

129. Ruben, F.L. \& LANE, J.M. (1970) Ocular vaccinia. Archives of Ophthalmology, 84, 45.

130. NefF, J.M. \& LANE, J.M. (1970) Vaccinia necrosum following smallpox vaccination for chronic herpetic ulcers. Journal of the American Medical Association, 212, 123.

131. Morris, L., Da Silva, O.J. \& Martinez, A.V. (1970) Epidemiologic investigation of a smallpox outbreak in a town reported to be ' $100 \%$ vaccinated'. American Journal of Epidemiology, 92, 294.

132. Smallpox may spread by air. (1970) Journal of the American Medical Association, 213, 635.

133. MACK, T.M. \& Noble, J. (1970) Natural transmission of smallpox from man to performing monkeys. Lancet, i, 752.

134. WARD, J.R. \& BISHOP, B. (1970) Varicella arthritis. Journal of the American Medical Association, 212, 1954.

135. NorRIs, F.H. et al. (1970) Herpes-zoster meningoencephalitis. Journal of Infectious Diseases, 122, 335.

136. Berlin, B.S. \& CAMpbell, T. (1970) Hospital acquired herpes zoster following exposure to chickenpox. Journal of the American Medical Association, 211, 1831.

137. Miller, L.H. \& Brunell, P.A. (1970) Zoster, reinfection or activation of latent virus? American Journal of Medicine, 49, 480.

138. HARDY, G.E. et al. (1970) The failure of a school immunization campaign to terminate an urban epidemic of measles. American Journal of Epidemiology, 91, 286.

139. Suringa, D.W.R., Bank, L.J. \& ACKerman, A.B. (1970) Role of measles virus in skin lesions and Koplik spots. New England Journal of Medicine, 283, 1139.

140. LeVITT, L.P. et al. (1970) Mumps in a general population. American Journal of Diseases of Children, 120, 134.

141. AdLER, J.R. et al. (1970) Epidemiologic investigation of hand, foot and mouth disease. American Journal of Diseases of Children, 120, 309.

142. Antigen-specific antibody found in trachoma patients. (1970) Journal of the American Medical Association, 212, 974.

143. Correa-Giron, E.P., Allen, R. \& Sulkin, S.E. (1970) The infectivity and pathogenesis of rabiesvirus administered orally. American Journal of Epidemiology, 91, 203.

144. Gonzales-Angulo, A. et al. (1970) Ultrastructure of Negri bodies in Purkinje neurons in human rabies. Neurology, 20, 323.

145. Sikes, R.K. (1970) Guidelines for the control of rabies. American Journal of Public Health and the Nation's Health, 60, 1133.

146. Horta-Barbosa, L. et al. (1970) Some characteristics of SSPE measles virus. Proceedings of the Society for Experimental Biology and Medicine, 134, 17.

147. Barbanti-Brodano, G. et al. (1970) Presence of two different viral agents in brain cells of patients with subacute sclerosing panencephalitis. Proceedings of the Society for Experimental Biology and Medicine, 134, 230.

148. LERICH, J.R. et al. (1970) Subacute sclerosing panencephalitis. Archives of Neurology, 23, 97.

149. Henson, T.W. et al. (1970) Measles antibody titers in multiple sclerosis patients, siblings, and controls. Journal of the American Medical Association, 211, 1985. 
150. Ehrenkrantz, N.J.et al. (1970) The natural occurrence of Venezuelian equine encephalitis in the United States. New England Journal of Medicine, 282, 298.

151. LORD, R.D. \& CALISHER, C.H. (1970) Further evidence of southward transport of arboviruses by migratory birds. American Journal of Epidemiology, 92, 73.

152. Illavia, S.J. \& WEBB, H.E. (1970) An encephalitogenic virus (Langat) in mice. Lancet, ii, 284.

153. ECKroAde, R.J. \& Zu RHeIN, G.M. (1970) Transmissible mink encephalopathy: Experimental transmission to the squirrel monkey. Science, 169, 1088.

154. VernON, M.L. et al. (1970) Virus-like particles and nucleoprotein type filaments in brain tissue from two patients with Creutzfeld-Jakob disease. Lancet, i, 964.

155. Phillips, P.E. \& Christian, C.L. (1970) Myxovirus antibody increases in human connective tissue. Science, 168, 982.

156. Hall, C.E., Cooney, M.K. \& Fox, J.P. (1970) The Seattle watch program. American Journal of Public Health and the Nation's Health, 60, 1456.

157. Virus-like structures and the connective tissue diseases. (1969). Bulletin of Rheumatic Diseases, 20, 575. Studies link viruses, connective tissue disease. Journal of the American Medical Association, 211, 385.

158. LevitT, L.P. et al. (1970) Meningococcal and Echo-9 meningitis. Neurology, 20, 45.

159. Mary, A.S. \& Swallow, J.H. (1970) An epidemic of ECHO 6 virus infection. Postgraduate Medical Journal, 46, 265.

160. HARFORD, C.G. et al. (1970) Human diploid cell cultures in diagnosis of echovirus 30 meningitis. Archives of Internal Medicine, 125, 864.

161. Gsell, O. (1970) Klinische Probleme der Meningitis und Enzephalitis. Deutsches Medizinisches Journal, 21, 135.

162. TORPHY, D.E. et al. (1970) Herpes simplex virus infection in infants. Journal of Pediatrics, 76, 405.

163. Miller, D.R. et al. Fatal disseminated herpes virus infection and hemorrhage in a neonate. Journal of Pediatrics, 76, 409.

164. ZAVORAL, J.H. et al. (1970) Neonatal herpetic infection. Journal of the American Medical Association, 213, 1492.

165. Aurelian, L., Royston, I. \& Davis, H.J. (1970) Antibody to genital herpes simplex virus: Association with cervical atypia and carcinoma in situ. Journal of the National Cancer Institute, 45, 455.

166. Rosato, F.E., Rosato, E.F. \& Plotkin, S.A. (1970) Herpetic paronychia-an occupational hazard of medical personnel. New England Journal of Medicine, 283, 804.

167. DiDERHOLM, H. et al. (1960) Herpes simplex hepatitis in an adult. Acta medica Scandinavica, 186, 151.

168. Morriseau, P.M., Phillips, C.A. \& Leadbetter, G.W. (1960) Viral prostatitis. Journal of Urology, 103, 767.

169. Herpesvirus infection in burned patients (1960) British Medical Journal, 2, 618.

170. MEYER, J.S. et al. (1970) Herpesvirus hominis encephalitis. Archives of Neurology, 23, 438.

171. Hirshaut, Y. et al. (1960) Sarcoidosis another disease associated with serologic evidence for herpes-like virus infection. New England Journal of Medicine, 283, 502.

172. E-B virus related to Hodgkin's disease. Journal of the American Medical Association, 212, 1451.

173. Goldman, J.M. \& Aisenberg, A. (1970) Incidence of antibody to EB virus, Herpes simplex, and Cytomegalovirus in Hodgkin's disease. Cancer, 26, 327.

174. Freedman, M.H., Gilchrist, G.S. \& Hammond, G.D. (1970) Concurrent infectious mononucleosis and acute leukemia. Journal of the American Medical Association, 214, 1677.
175. Banatvala, J.E. (1970) Annotation: Infectious mononucleosis: Recent developments. British Journal of Haematology, 19, 129.

176. Gallmeier, W.M. et al. (1970) Occurrence of antibodies against Burkitt's lymphoma virus (Epstein-Barr virus) in Germany. Deutsche medizinische Wochenschrift, 95, 1297.

177. Tischendorf, P. et al. (1960) Development and persistence of immunity to Epstein-Barr virus in man. Journal of Infectious Diseases, 122, 401.

178. O'ConoR, G.T. (1970) Persistent immunologic stimulation as a factor in oncogenesis, with special reference to Burkitt's tumor. American Journal of Medicine, 48, 279. Burkitt lymphoma and Malaria (1970) Editorial, Lancet, ii, 300.

179. Malaria and Lymphoma. (1970) Lancet, ii, 1121.

180. CoHeN, M.H. et al. (1970) Infectious mononucleosis followed by Burkitt's tumor. Annals of Internal Medicine, 73, 591.

181. Klemola, E. et al. (1970) Infectious-mononucleosislike disease with negative heterophil agglutination test. Features in relation to Epstein-Barr virus and cytomegalovirus antibodies. Journal of Infectious Diseases, 121,608

182. Cells from mononucleosis patient cause tumors. (1970) Journal of American Medical Association, 212, 2032.

183. BlaCkLOW, N.R. \& KaPIKIAN, A.Z. (1970) Serological studies with EB virus in infectious lymphocytosis. Nature, 226, 647.

184. Gsell, H.O., Löffler, H. \& Muller, B. (1970) Serum antibodies against Epstein-Barr virus in infectious mononucleosis. Schweizerische medizinische Wochenschrift, 100, 495.

185. Niederman, J.C. et al. (1970) Prevalence, incidence and persistence of EB virus antibody in young adults New England Journal of Medicine, 282, 361.

186. Stevens, D.A., Pry, T.W. \& Manaker, R.A. (1970) Infections mononucleosis-always a primary infection. Journal of the National Cancer Institute, 44, 533.

187. WAHREN, B. et al. (1970) EBV antibodies in family contacts of patients with infectious mononucleosis. Proceedings of the Society for Experimental Biology and Medicine, 133, 934.

188. LehaNe, E.D. (1970) A seroepidemiologic study of infectious mononucleosis. Journal of the American Medical Association, 212, 2240.

189. Henle G. \& Henle, W. (1970) EB virus in the etiology of infectious mononucleosis. Hospital Practice, 5, 33.

190. Henle, W. et al. (1970) Antibody responses to the Epstein-Barr virus and cytomegaloviruses after openheart and other surgery. New England Journal of Medicine, 282, 1068.

191. Henle, G. \& Henle, W. (1970) Observations on childhood infections with the Epstein-Barr virus. Journal of Infectious Diseases, 121, 303.

192. Stark, J.G., BART, R.D. \& Gold, E. (1970) Inapparent congenital cytomegalovirus infection. New England Journal of Medicine, 282, 1075.

193. NumazaKI, Y. et al. (1970) Primary infection with human cytomegalovirus: Virus isolation from healthy $N$ infants and pregnant women. American Journal of Epidemiology, 91, 410.

194. LeVITT, L.P., Wolfe, V. \& Bond, J.O. (1970) Winter vomiting disease in Florida students. Journal of 0 Hygiene, 68, 1.

195. Massillamony, R.P. \& John, T.J. (1970) Experimental reovirus infection in monkeys. American Journal of Epidemiology, 91, 446.

196. Monif, G.R.G. \& Hood, C.I. (1970) Ileocolitis associated with measles (Rubeola). American Journal of Diseases of Children, 120, 245. 
197. Dolin, R. et al. (1970) Establishment of human fetal intestinal organ cultures for growth of viruses. Journal of Infectious Diseases, 122, 227.

198. Royston, I. \& AUrelian, L. (1970) The association of genital herpesvirus with cervical atypia and carcinoma in situ. American Journal of Epidemiology, 91, 531.

199. Nahmias, A.J. et al. (1970) Antibodies to herpes virus hominis types 1 and 2 . II. Women with cervical cancer. American Journal of Epidemiology, 91, 547.

200. GoodhearT, C.R. (1970) Herpes viruses and cancer. Journal of the American Medical Association, 211, 91.

201. RAWLS, W.E., GARDNER, H.L. \& KaUfMAN, R.L. (1970) Antibodies to genital herpes virus in patients with carcinoma of the cervix. American Journal of Obstetrics and Gynecology, 107, 710.

202. STOKer, M. (1970) New growth and viruses. British Medical Journal, 3, 541.

203. Virus theory of sarcomas gains support. (1970) Journal of the American Medical Association, 213, 537.

204. Hunter-Craig, I. et al. (1970) Use of vaccinia virus in the treatment of metastatic malignant melanoma. British Medical Journal, 2, 512.

205. Virus found in monkey breast cancer. (1970) Journal of the American Medical Association, 212, 718.

206. SARMA, P.S. et al. (1970) Feline leukemia and sarcoma viruses: susceptibility of human cells to infection. Science, 168, 1098.

207. BAZELl, R.J. (1970) Cancer research: Senate consultant likely to push for a planned assault. Science, 170, 304.

208. Grausz, H. et al. (1970) Diagnostic import of virus-like particles in the glomerular endothelium of patients with systemic lupus erythematosus. New England Journal of Medicine, 283, 506.

209. Mitchell, D.N. \& Rees, R.J.W. (1970) Agent transmissible from Crohn's disease. Lancet, ii, 168.

210. KRUEGER, R.F. \& MAYER, G.D. (1970) Tirolone hydrochloride: an orally active antiviral agent. Science, 169, 1213.

211. Armstrong, R.N. et al. (1970) Cutaneous interferon production in patients with Hodgkin's disease and other cancers infected with varicella or vaccinia. New England Journal of Medicine, 283, 1182.

212. Musher, D.M., RatTZAN, K.R. \& Weinstein, L. (1970) The effect of Listeria Monocytogenes on resistance to pneumococcal infection. Proceedings of the Society for Experimental Biology and Medicine, 135, 557.

213. Cluff, L.E. (1970) Effects of endotoxins on susceptibility to infections. Journal of Infectious Diseases, 122, 205.

214. Moellering, R.C. \& Weinberg, A.N. (1970) Persistent salmonella infection in a female carrier for chronic granulomatous disease. Annals of Internal Medicine, 73, 595.

215. KenNy, G.E., CoONey, M.K. \& Thompson, D.J. (1970) Analysis of serum pooling schemes for identification of large numbers of viruses. American Journal of Epidemiology, 91, 439.

216. Nahmias, A.J. (1970) Fluorescent antibody technique in clinical microbiology. Hospital Practice, 5, 53.

217. Role of $T$ strains in gu ills studied. (1970) Hospital Tribune, 4, 3.

218. BraUn, P. et al. (1970) Methodologic investigations and prevalence of genital mycoplasmas in pregnancy. Journal of Infectious Diseases, 121, 391.

219. Kundsin, R.B. \& Driscoll, S.G. (1970) Mycoplasmas and human reproductive failure. Surgery, Obstetrics and Gynecology, 131, 89.

220. Gregory, J.E. \& PAYne, F.E. (1970) Mycoplasma in uterine cervix. American Journal of Obstetrics and Gynecology, 107, 220.
221. Shepard, M.C. (1970) Nongonococcal urethritis associated with human strains of ' $\mathrm{T}$ ' mycoplasmas. Journal of the American Medical Association, 211, 1335.

222. Williams, M.H., Brostoff, J. \& Roitt, I.M. (1970) Possible role of Mycoplasma fermentans in pathogenesis of rheumatoid arthritis. Lancet, ii, 277.

223. Sacker, I., WAlker, M. \& Brunell, P.A. (1970) Abscess in newborn infants caused by mycoplasma. Pediatrics, 46, 303.

224. Reller, L.B., Gangarosa, E.J. \& Brachman, P.S. (1970) Shigellosis in the United States: Five-year review of nationwide surveillance. American Journal of Epidemiology, 91, 161.

225. ToNG, M.J. et al. (1970) Clinical and bacteriological evaluation of antibiotic treatment in shigellosis. Journal of the American Medical Association, 214, 1841.

226. Antibiotics in gastroenteritis. (1970) Lancet, ii, 1169.

227. Rowe, E., TAylor, J. \& Bettelheim, K.A. (1970) An investigation of travellers' diarrhoea. Lancet, $\mathbf{i}, 1$.

228. GoRbaCH, S.L. (1970) Acute diarrhea-a 'toxin' disease? New England Journal of Medicine, 283, 44.

229. DuPONT, H.L. et al (1970) Evaluation of chloramphenicol acid succinate therapy of induced typhoid fever and Rocky Mountain spotted fever. New England Journal of Medicine, 282, 53.

230. Reynolds, D.W., Carpenter, R.L. \& Simon, W.H. (1970) Diagnostic specificity of Widal's reaction for typhoid fever. Journal of the American Medical Association, 214, 2192.

231. Oral live virus typhoid vaccine tests show promise. (1970) Journal of the American Medical Association, 214, 991.

232. Adams, A.P. \& Spendlove, J.C. (1970) Coliform aerosols emitted by sewage treatment plants. Science, 169, 1218.

233. GoRBACH, S.L. et al. (1970) Intestinal microflora in a chronic carrier of Vibrio cholerae. Journal of Infectious Diseases, 121, 383.

233a. PIERCE, N.F. et al. (1970) Convalescent carriers of Vibrio cholerae. Annals of Internal Medicine, 72, 357.

234. Music, S.I. et al. (1970) Induced human cholera. Progress of the American Society for Clinical Investigations, 4 May, 69.

235. ReimanN, H.A. (1948) Cholera, chap. 24, p. 797. Oxford Med.

236. CASH, R.A. et al. (1970) A clinical trial of oral therapy in a rural cholera-treatment centre. American Journal of Tropical Medicine and Hygiene, 19, 653.

237. Felsenfeld, O. (1970) The Cholera Problem, p. 180. Warren Green Inc. St Louis.

238. Cholera case in Britain (1970) British Medical Journal, 4,61 .

239. ZAMIRI, I. (1970) Diphtheria today. Some experiences in Iran. Lancet, i, 1222.

240. Zalma, V.M., Older, J.J. \& Brooks, G.F. (1970) The Austin, Texas, diphtheria outbreak. Journal of the American Medical Association, 211, 2125.

241. Diphtheria kills two in Chicago; vaccine given. (1970) Journal of the American Medical Association, 211, 754.

242. Legters, L.J., Cottingham, A.J. \& Hunter, D.H. (1970) Clinical and epidemiologic notes on a defined outbreak of plague in Vietnam. American Journal of Tropical Medicine and Hygiene, 19, 639.

243. Shrewsbury, J.F.D. (1970) History of Bubonic Plague in the British Isles, p. 661. Cambridge University Press, London.

244. Weber, J., Finlayson, N.B. \& Mark, J.B.D. (1970) Mesenteric lymphadenitis and terminal ileitis due to Yersinia pseudotuberculosis. New England Journal of Medicine, 283, 172. 
245. Comstock, G.W. \& Webster, R.G. (1970) Tuberculosis studies in Muscagee County Georgia. VII. Twenty-year evaluation. American Review of Respiratory Diseases, $100,839$.

246. Comstock, G.W., Hammes, L.M. \& Pio, A. Isoniazid prophylaxis in Alaskan boarding schools. American Review of Respiratory Diseases, 100, 773.

247. KATz, S. (1970) Primary drug resistance in tuberculo sis. Journal of the American Medical Association, 212, 2113.

248. Rytel, M.W., Davis, E.S. \& Prebil, K.J. (1970) Primary cutaneous inoculation of tuberculosis. American Review of Respiratory Diseases, 102, 264.

249. Bowry, S. et al. (1970) Hepatic involvement in pulmonary tuberculosis. American Review of Respiratory Diseases, 101, 941.

250. Fogan, L. (1970) Atypical mycobacteria. Their clinical, laboratory and epidemiologic significance. Medicine, 49, 243.

251. Adams, R.M. et al. (1970) Tropical fish aquariums. A source of Mycobacterium marinum infections resembling sporotrichosis. Journal of the American Medical Assotion, 211, 457.

252. Flowers, D.J. (1970) Human infection due to Mycobacterium marinum after a dolphin bite. Journal of Clinical Pathology, 23, 475.

253. GryskA, P.F. \& O'DEA, A.E. (1970) Postoperative streptococcal wound infection. Journal of the American Medical Association, 213, 1189.

254. WANNAMAKER, L.W. Differences between streptococcal infections of the throat and of the skin. New England Journal of Medicine, 282, 78.

255. Bisno, A.L. et al. (1970) Contrasting epidemiology of acute rheumatic fever and acute glomerulonephritis. Nature of the antecedent streptococcal infection. New England Journal of Medicine, 283, 832.

256. Ferrieri, P. et al. (1970) Appearance of nephritis associated with Type 57 streptococcal impetigo in North America. New England Journal of Medicine, 283, 832.

257. Phibbs, B., TAylor, J. \& Zimmerman, R.A. (1970) A community-wide streptococcal control project. Journal of the American Medical Association, 214, 2018.

258. DucA, E. et al. (1969) New nephritogenic streptococcus. Journal of Hygiene, 67, 691.

259. Finland, M. \& BARNes, M.W. (1970) Changing etiology of bacterial endocarditis in the antibacterial era. Annals of Internal Medicine, 72, 341.

260. Levison, M.E. et al. (1970) Characteristics of patients with multiple episodes of bacterial endocarditis. Journal of the American Medical Association, 211, 1355.

261. Ellner, P.D. (1970) Endocarditis due to Group L streptococcus. Annals of Internal Medicine, 72, 547.

262. Williams, J.C. \& Johnson, J.E. (1970) Serratia marcescens endocarditis. Archives of Internal Medicine, 125, 1038

263. Felner, J.M. \& Dowell, V.R. (1971) Anaerobic bacterial endocarditis. New England Journal of Medicine, 283, 1188.

263a. Bunting, M.I. (1940) A description of some color variants produced by Serratia marcescens, strain 274. Journal of Bacteriology, 40, 57.

264. Hairston, P. \& Lee, W.H. (1970) Management of infected prosthetic heart valves. Annals of Thoracic Surgery, 9, 229.

265. OKIES, J.E. et al. (1970) Valvular replacement in bacterial endocarditis. Bulletin of the Baylor College of Medicine, 8, 126.

266. Bell, E.J. \& GRIST, N.R. (1970) Echoviruses, carditis and acute pleurodynia. Lancet, $\mathbf{i}, 326$.
267. Meehan, W.F. \& Bertrand, C.A. (1970) Ventricular tachycardia associated with echovirus infection. Journal of the American Medical Association, 212, 1701.

268. Feinstein, A.R. \& LevitT, M. (1970) The role of tonsils in predisposing to streptococcal infections and recurrences of rheumatic fever. New England Journal of Medicine, 282, 285.

269. ReimanN, H.A. \& Havens, W.P. (1940) Focal infections and systemic disease: A critical appraisal. The case against indiscriminate removal of teeth and tonsils. Journal of the American Medical Association, 114, 1.

270. Value of tonsillectomy questioned (1970) Journal of the American Medical Association, 212, 1135.

271. ReINARZ, J.A. et al. (1970) Meningococcal disease due to Group C organisms. Program of the American College of Physicians, 16 April, 119.

272. HAND, W.L. \& SANFord, J.P. (1970) Post traumatic bacterial meningitis. Annals of Internal Medicine, 72, 869.

273. MCHenry, M.C. et al. (1970) Meningitis due to Escherichia coli. Journal of the American Medical is Association, 212, 156.

274. Eichner, H.L. \& Deller, J.J. (1970) Meningococcal arthritis. Report of two cases. Arthritis and Rheumatism, 13, 272.

275. Artenstein, M.S. et al. (1970) Prevention of meningococcal disease by Group $C$ polysaccharide vaccine. New England Journal of Medicine, 282, 417.

276. Overall, J.C. (1970) Neonatal bacterial meningitis. Journal of Pediatrics, 76, 499.

277. Balagtas, R.C. et al. (1970) Seconary and prolonged fevers in bacterial meningitis. Journal of Pediatrics, 76 499.

278. Definitions and classifications of infectious reactions 8 the lung. (1970) Medical Section of the Nationa Tuberculosis Association. American Review of Respirct tory Diseases, 101, 116.

279. Reimann, H.A. (1971) Pneumonias. Warren Green, Inc. St Louis. (In press.)

280. PARKeR, R.H. et al. (1970) Erythromycin-resistant pneumococcal osteomyelitis. American Journal of $\overline{\bar{B}}$ Medicine, 48, 32.

281. Calder, M.A., Mchardy, V.U. \& Schonell, M.E. (1970) Importance of pneumococcal typing in pneumonia. Lancet, i, 5.

282. KABINS, S.A. \& LERner, C. (1970) Fulminant pneumococcemia and sickle cell anemia. Journal of the American Medical Association, 211, 467.

283. Stossel, T.P. \& LEvy, R. (1970) Intravascular coagulation associated with pneumococcal bacteremia and symmetrical peripheral gangrene. Archives of Internal Medicine, 125, 876.

284. PutsCh, R.W., Hamilton, J.D. \& Wolinsky, E. (1970) Neisseria meningitidis, a respiratory pathogen? Journal of Infectious Diseases, 121, 48.

285. Rogers, L.A. (1970) Pneumonia following tracheostomy. American Surgeon, 36, 39.

286. Huber, G.L. \& LA Force, F.M. (1970) Progressive impairment of pulmonary antibacterial defense mechanisms associated with prolonged oxygen administra- $\omega$ tion. Program of the American College of Physicians, April, 135.

287. Goodell, B. et al. (1970) Pneumocystis carinii: The spectrum of diffuse interstitial pneumonias in patients with neoplastic diseases. Annals of Internal Medicine, 72, 337.

288. Johnson, H.D. \& Johnson, W.W. (1970) Pneumocystis carinii pneumonia in children with cancer. Journal of $\mathbb{D}$ the American Medical Association, 214, 1067. 
289. Perera, D.R. et al. (1970) Pneumocystis carinii pneumonia in a hospital for children. Journal of the American Medical Association, 214, 1074.

290. NiITA, Y. et al. (1970) Resistance of Mycoplasma pneumoniae to erythromycin and other antibiotics. Journal of Pediatrics, 76, 438.

291. VD incidence reaches pandemic proportions. American Medical News, 23 Nov., 12.

292. Brown, W.J. (1970) Eradication of syphilis: The missing element. Annals of Internal Medicine, 72, 278. Gonorrhea: not yet controllable. Annals of Internal Medicine, 72, 280.

293. Three groups cite 'soaring' rise of gonorrhea. (1970) Hospital Tribune, 4, 3.

294. Fleming, W.L. et al. (1970) National survey of venereal disease treated by physicians in 1968. Journal of the American Medical Association, 211, 1827.

295. Holmes, K.G., Johnson, D.W. \& Trostle, H.J. (1970) An estimate of the risk of men acquiring gonorrhea by sexual contact with infected females. American Journal of Epidemiology, 91, 170.

296. Metzger, A.L. (1970) Gonococcal arthritis complicating gonorrheal pharyngitis. Annals of Internal Medicine, 73, 267.

297. SWIERCZEWSKI, J.A. et al. (1970) Fulminating meningitis with Waterhouse-Friderichsen syndrome due to Neisseria gonorrheae. American Journal of Clinical Pathology, 54, 202.

298. Kimball, M.W. \& KNeE, S. (1970) Gonococcal perihepatitis in a male. New England Journal of Medicine, 282, 1082.

299. ACKerman, A.B. (1970) Hemorrhagic bullae in gonococcemia. New England Journal of Medicine, 282, 793

300. WolfF, C.B., Goodman, H.V. \& VahrmaN, J. (1970) Gonorrhea with skin and joint manifestations. Lancet, i, 271.

301. Schroeter, A.L. \& Pazin, G.L. (1970) Gonorrhea. Annals of Internal Medicine, 72, 553.

302. Gonococci live for days in transport medium. (1970) Journal of the American Medical Association, 213, 1571.

303. HARDY, J.B. et al. (1970) Failure of penicillin in a newborn with congenital syphilis. Journal of the American Medical Association, 212, 1345.

304. Fiumara, N.J. \& Lessell, S. (1970) Manifestations of late congenital syphilis. Archives of Dermatology, 102, 78.

305. Reddy, P. et al. (1970) Progressive disseminated histoplasmosis as seen in adults. American Journal of Medicine, 48, 629.

306. Aldridge, M.J. et al. (1970) Case of disseminated histoplasmosis. British Medical Journal, 4, 33.

307. Prathapchandra, A.R. et al. (1970) Peritonitis due to histoplasmosis. Annals of Internal Medicine, 72, 79.

308. Lanza, F.L., Nelson, R.S. \& Somayaji, B.N. (1970) Acute granulomatous hepatitis due to histoplasmosis. Gastroenterology, 58, 392.

309. Samovitz, M. \& Dillon, T.K. (1970) Disseminated histoplasmosis presenting as exfoliative erythroderma. Archives of Dermatology, 101, 216.

310. Dodge, H.J., Engelke, O.K. \& DoHm, K.M. (1970) Observations on the decline of histoplasmal infections in school children: Milan, Michigan, 1958-68. American Journal of Public Health and the Nation's Health, 60, 1442.

311. Tosh, F.E. et al. (1970) Relationship of starling-blackbird roosts and endemic histoplasmosis. American Review of Respiratory Diseases, 101, 283.

312. Chaves-Carballo, E. (1970) Samuel T. Darling and human sarcoporidiosis or toxoplasmosis in Panama. Journal of the American Medical Association, 211, 1687.
313. Teel, K.W., Yow, M.D. \& Williams, T.W. (1970) A localized outbreak of coccidioidomycosis in southern Texas. Journal of Pediatrics, 77, 65.

314. RAMras, D.H. et al. (1970) An epidemic of coccidioidomycosis. in the Pacific Beach area of San Diego American Review of Respiratory Diseases, 101, 975.

315. Smale, L.E. \& Waechter, K.G. (1970) Dissemination of coccidioidomycosis in pregnancy. American Journal of Obstetrics and Gynecology, 107, 356.

316. SARosi, G.A. et al. (1970) Chronic pulmonary coccidioidomycosis. New England Journal of Medicine, 283, 325 .

317. Caudill, R.H., Smith, C.E. \& Reinarz, J.A. (1970) Coccidioidal meningitis. A diagnostic challenge. American Journal of Medicine, 49, 360.

318. LyNCh, P.J., VoORhees, J.J. \& HARrell, E.R. (1970) Systemic sporotrichosis. Annals of Internal Medicine, 73, 23.

319. BanaszaK, E.F., Thiede, W.H. \& Fink, J.N. (1970) Hypersensitivity pneumonitis due to contaminated air conditioner. New England Journal of Medicine, 283, 271.

320. AshCraft, K.W. \& LeaPe, L.L. (1970) Candida sepsis complicating parenteral feeding. Journal of American Medical Association, 212, 454.

321. Montes, L.F. (1970) Systemic abnormalities and the intracellular site of infections of the stratum corneum. Journal of the American Medical Association, 213, 1469.

322. Levin, S. (1970) The fungal skin test as a diagnostic hindrance. Journal of Infectious Diseases, 122, 343.

323. Klainer, A.S. \& BeISEL, W.R. (1969) Opportunistic infertions: A review. American Journal of Medical Sciences, 258, 416.

324. ZABRANSKY, R.J. (1970) Isolation of anaerobic bacteria from clinical specimens. Proceedings of the Staff Meetings of the Mayo Clinic, 45, 256.

325. Pearson, H.E. \& Anderson, G.V. (1970) Bacteroides infections in pregnancy. Obstetrics and Gynecology, 35, 31.

326. Gelb, A.F. \& Seligman, S.J. (1970) Bacteroidaciea bacteremia. Journal of the American Medical Association, 212, 1038.

327. Goodman, J.S., Bodner, S.J. \& Koenig, M.C. (1970) Program of the American College of Physicians, 16 April, 103.

328. Hermans, P.E. \& Washington, J.A. (1970) Polymicrobial bacteremia. Annals of Internal Medicine, 73, 387.

329. Dans, P.E. et al. (1970) Klebsiella enterobacter at Boston City Hospital, 1967. Archives of Internal Medicine, 125, 94.

330. Bodey, G.P. (1970) Epidemiological studies of Pseudomonas species in patients with leukemia. American Journal of Medical Sciences, 260, 82.

331. SACK, R.A. (1970) Epidemic of Gram-negative organism septicemia subsequent to elective operation. American Journal of Obstetrics and Gynecology, 107, 394.

332. SANDERS, C.V. et al. (1970) Serratia marcescens infections from inhalation therapy medications: Nosocomial outbreak. Annals of Internal Medicine, 73, 15.

333. GARDNER, P. et al. (1970) Nonfermentative Gramnegative bacilli of nosocomial interest. American Journal of Medicine, 48, 735.

334. WhITEHOUSE, F.W. (1970) Infections causing hospitalization in patients with diabetes. Program of the American College of Physicians, April, 89.

335. LeVI, J., Robson, M. \& Rosenfeld, J.B. (1970) Septicaemia and pulmonary embolism complicating use of arteriovenous fistula in maintenance of hemodialysis. Lancet, ii, 289. 
336. RAmes, L. et al. (1970) Renal disease with Staphylococcus albus bacteremia. A complication in ventriculoatrial shunts. Journal of the American Medical Association, 212, 1671.

337. Subphrenic abscess: A changing pattern. (1970) Editorial. Lancet, ii, 301.

338. Adner, M.M., KAuff, R.E. \& Sherman, J.D. (1 770$)$ Purpura fulminans in a child with pneumococcal septicemia two years after splenectomy. Journal of the American Medical Association, 213, 1681.

339. Sever, J.L. (1970) Viral teratogens: A status report. Hospital Practice, 7, 75.

340. Toala, P., McDonald, A. \& Kass, E.H. (1770) Septicemia caused by Vibrio fetus. Archives of Internal Medicine, 126, 306.

341. BoKKenhauser, V. (1970) Vibrio fetus infection in man. American Journal of Epidemiology, 91, 400.

342. Mavligit, G. (1970) Candida endocarditis of the tricuspid valve. Journal of the American Medical Association, 213, 1906.

343. Groote, C.A. (1970) Rhinocerebral phycomycosis. Archives of Otolaryngology, 92, 288.

344. Marks, M.I., LANGSTON, C. \& EICkhoff, T.C. (1970) Torulopis glabrata - an opportunistic pathogen in man. New England Journal of Medicine, 383, 1131.

345. Guenter, C.A. \& Hinshaw, L.B. (1970) Comparison of septic shock due to Gram-negative and Grampositive organisms. Proceedings of the Society of Experimental Biology and Medicine, 134, 780.

346. AlPER, C.A. et al. (1970) Complement defect associated with increased susceptibility to infection. New England Journal of Medicine, 282, 349.

347. Miller, M.E. \& UlF, R.J. (1970) A familial deficiency of the phagocytosis-enhancing activity of serum related to a dysfunction of the fifth component of complement (C5). New England Journal of Medicine, 282, 354.

348. Opsonins. (1970) New England Journal of Medicine, 282, 391.

349. Recurrent infections and deficiency of complement. British Medical Journal, $2,744$.

350. SCHUR, P.H. et al. (1970) Selective gamma-g globulin deficiencies in patients with recurrent pyogenic infections. New England Journal of Medicine, 283, 631.

351. Chapman, J.S. (1970) Animal-to-human infection. Journal of the American Medical Association, 213, 1559.

352. Hubbert, W.T. \& Rosen, M.N. (1970) I. Pasteurella multocida infection due to animal bite. American Journal of Public Health and the Nation's Health, 60, 1103. II. Pasteurella multocida infection in man unrelated to animal bite. American Journal of Public Health and the Nation's Health, 60, 1109.

353. Piggot, J.A. \& Hochholzer, L. (1970) Human melioidosis. Archives of Pathology, 90, 101.

354. SHooter, R.A. et al. (1970) Animal sources of common serotypes of Escherichia coli in food of hospital patients. Lancet, ii, 226.

355. Food-borne Infections and Intoxications (1970) (Ed. by Hans Riemann), pp. 3-698. Academic Press, New York and London.

355a. MuUL, I. (1970) Mammalian ecology and epidemiology of zoonoses. Science, 170, 1275.

356. Bozeman, F.M. et al. (1970) Serologic evidence of Rickettsia canada infection of man. Journal of Infectious Diseases, 121, 367.

357. Calia, F.M., Bartelloni, P.J. \& McKinney, R.W. (1970) Rocky Mountain spotted fever. Laboratory infection in vaccinated individuals. Journal of the American Medical Association, 211, 2012.

358. OLDER, J.J. (1970) The epidemiology of murine typhus in Texas, 1969. Journal of the American Medical Association, 214, 1011.
359. CARrithers, H.A. (1970) Cat-scratch disease. American Journal of Diseases of Children, 119, 200.

360. Buescher, E.L. et al. (1970) Cache Valley virus in the Del Mar Va Peninsula. American Journal of Tropical Medicine and Hygiene, 19, 493.

361. CAlisher, C.H. et al. (1970) Tamiami virus, a new $\overrightarrow{\vec{F}}$ member of the Tacaribe group. American Journal of Tropical Medicine and Hygiene, 19, 520.

362. CAMPbell, C.H., Webster, R.G. \& BREeSe, S.S. (1970) 흐 Fowl plague virus from man. Journal of Infectious Diseases, 122, 513.

363. NAGGAN, L. et al. (1970) Ecology and attempted control of cutaneous leishmaniasis around Jericho, in the Jordan valley. Journal of Infectious Diseases, 121, 427. $\vec{\square}$

364. Saloman, P.F., CatTs, E.P. \& Knox, W.G. (1970) Human dermal myiasis caused by rabbit bot fly in $\overrightarrow{\vec{\omega}}$ Connecticut. Journal of the American Medical Association, 213, 1035.

365. Hermos, J.A. et al. (1970) Fatal human cerebral coenurosis. Journal of the American Medical Association, 213, 1461.

366. SCHACHER, J.C. \& HAJJ, S.N. (1970) Taenia proglottid iv in the human uterus. American Journal of Tropical + Medicine and Hygiene, 19, 626.

367. Garnham, P.C.C. et al. (1969) Human babesiosis in $\omega$ Ireland. British Medical Journal, 4, 768. FirzPATRICK, J.E.P. et al. (1969) Further details of third recorded case of redwater (Babiosis) in man. British Medical Journal, 4, 770.

368. WoodrufF, A.W. (1970) Toxocariasis. British Medical Journal, 3, 663 .

369. Wiseman, R.A., Fleck, D.G. \& WoodrufF, A.W. $\overrightarrow{0}$ (1970) Toxoplasmal and toxocaral infections: A clinigi $1 \stackrel{-}{-}$ investigation into their relationship. British Medial Journal, 4, 152.

370. FörTSCH, D. \& DvorÁCKLOVÁ, I. (1970) Toxoplası̣̂a encephalitis in adults. Deutsche medizinische Wochenschrift, 95, 2362.

371. TORTEN, M. et al. (1970) Epidemiologic investigations $\frac{0}{(1)}$ of an outbreak of leptospirosis in the upper Galilee, 을 Israel. American Journal of Epidemiology, 91, 52.

372. Human eye infections due to feline virus. (1970) $\frac{\mathrm{O}}{3}$ Journal of the American Medical Association, 212, 2271.

373. Hardman, E.W., Jones, R.L.H. \& Davies, A.H. (1970)官 Fascioliasis-a large outbreak. British Mdeical Journal, 3, 502.

374. BRANDBorg, L.L., Goldberg, S.B. \& BreidenbaCH, W.C. (1970) Human coccidiosis-A possible cause of $\overline{0}$ malabsorption. New England Journal of Medicine, 283, 1306.

375. Pelaez, D. \& Peres-Reyes, R. (1970) Human gnathostomiasis in America. Revist. Latinoamericana de microbiologia, 12, 83.

376. KunIN, C.M. (1970) The natural history of recurrent $D$ bacteriuria in schoolgirls. New England Journal of Medicine, 282, 1443. A ten-year study of bacteriuria in schoolgirls: Final report of bacteriologic, urologic, and $N$ epidemiologic findings. Journal of Infectious Diseases, 122, 382.

377. ThORTON, G.F. \& ANDRIOLE, V.T. (1970) Bacteriuria N during indwelling catheter drainage. Journal of the American Medical Association, 214, 339.

378. NeVA, F.A. et al. (1970) Malaria: Host defense mech- $-\subseteq$ anism and complications. Annals of Internal Medicine, $\mathbb{D}$ 73, 295.

379. Mathews, H.M., Fisher, G.V. \& KagAN, I.G. (1970) Persistence of malaria antibody in Tobago, Westo Indies, following eradication. American Journal of Tropical Medicine and Hygiene, 19, 581. 
380. D'Antonio, L.E. et al. (1970) Malaria resistance: artificial induction with a partially purified plasmodial fraction. Science, 168, 1117.

381. Duma, R.J. (1970) Primary amebic meningoencephalitis. Program of the American College of Physicians, April, 121.

382. Apley, J. et al. (1970) Primary amoebic meningoencephalitis in Britain. British Medical Journal, 1, 596.

383. Morris, M.N., Powell, S.J. \& Elsdon-DEW, R. (1970) Latex agglutination test for invasive amaebiasis. Lancet, i, 1362.

384. ScotT, F. \& Miller, M.J. (1970) Trials with metronidazole in amebic dysentery. Journal of the American Medical Association, 211, 118.

385. Altemeier, W.A. (1970) Abscesses of the liver. Archives of Surgery, 101, 258.

386. Clark, W.D. et al. (1970) Acute schistosomiasis mansoni in 10 boys. An outbreak in Caguas, Puerto Rico. Annals of Internal Medicine, 73, 379.
387. Mining an abandoned vein. Journal of the American Medical Association, 211, 1536.

388. Mahoney, L.E. \& AiU, P. (1970) Filariasis in Samoan immigrants to the United States. American Journal of Tropical Medicine and Hygiene, 19, 629.

389. SMITH, D.T. (1970) Autogenous vaccines in theory and in practice. Archives of Internal Medicine, 125, 344.

390. SACKs, A. (1970) Active immunoprophylaxis in burns with a new multivalent vaccine. Lancet, ii, 959.

391. Infant immunization surveillance: Cost vs effect. Journal of the American Medical Association, 212, 770.

392. Goldring, I.P., RATNER, I.M. \& GReENBERG, L. (1970) Pulmonary hemorrhage in hamsters after exposure to proteolytic enzymes of Bacillus subtilis. Science, 170, 73 .

393. Tullis, D.C.H. (1970) Bronchial asthma associated with intestinal parasites. New England Journal of Medicine, 282, 370.

394. The Navaho (1970) Journal of the American Medical Association, 213, 17. 